\title{
Bacteriophages as an Alternative Method for Control of Zoonotic and Foodborne Pathogens
}

\author{
Mohammed Mijbas Mohammed Alomari ${ }^{1}$, Marta Dec ${ }^{2}$ (D) and Renata Urban-Chmiel ${ }^{2, *(D)}$ \\ 1 Faculty of Veterinary Medicine, University of Al Muthanna, Samawah 66001, Iraq; mijbas83@gmail.com \\ 2 Department of Veterinary Prevention and Avian Diseases, Faculty of Veterinary Medicine University of Life \\ Sciences in Lublin, 20-033 Lublin, Poland; marta.dec@up.lublin.pl \\ * Correspondence: renata.urban@up.lublin.pl
}

Citation: Alomari, M.M.M.; Dec, M.; Urban-Chmiel, R. Bacteriophages as an Alternative Method for Control of Zoonotic and Foodborne Pathogens. Viruses 2021, 13, 2348. https:// doi.org/10.3390/v13122348

Academic Editors:

Zuzanna Drulis-Kawa and Daria Augustyniak

Received: 28 October 2021

Accepted: 22 November 2021

Published: 23 November 2021

Publisher's Note: MDPI stays neutral with regard to jurisdictional claims in published maps and institutional affiliations.

Copyright: (c) 2021 by the authors. Licensee MDPI, Basel, Switzerland. This article is an open access article distributed under the terms and conditions of the Creative Commons Attribution (CC BY) license (https:// creativecommons.org/licenses/by/ $4.0 /)$.

\begin{abstract}
The global increase in multidrug-resistant infections caused by various pathogens has raised concerns in human and veterinary medicine. This has renewed interest in the development of alternative methods to antibiotics, including the use of bacteriophages for controlling bacterial infections. The aim of this review is to present potential uses of bacteriophages as an alternative to antibiotics in the control of bacterial infections caused by multidrug-resistant bacteria posing a risk to humans, with particular emphasis on foodborne and zoonotic pathogens. A varied therapeutic and immunomodulatory (activation or suppression) effect of bacteriophages on humoral and cellular immune response mechanisms has been demonstrated. The antibiotic resistance crisis caused by global antimicrobial resistance among bacteria creates a compelling need for alternative safe and selectively effective antibacterial agents. Bacteriophages have many properties indicating their potential suitability as therapeutic and/or prophylactic agents. In many cases, bacteriophages can also be used in food quality control against microorganisms such as Salmonella, Escherichia coli, Listeria, Campylobacter and others. Future research will provide potential alternative solutions using bacteriophages to treat infections caused by multidrug-resistant bacteria.
\end{abstract}

Keywords: bacteriophages; foodborne pathogens; antimicrobial resistance; zoonotic bacteria

\section{Introduction}

Zoonotic pathogens cause problems all over the world, including diseases such as anthrax, brucellosis, bovine tuberculosis, hydatid disease, echinococcosis, trichinellosis, rabies, highly pathogenic avian influenza, Nipah/Hendra disease and bovine spongiform encephalopathy. In 2015, the WHO reported that more than 600 million people (1 in 10) worldwide fell ill as a result of foodborne infections [1,2]. According to the European Food Safety Authority (EFSA), the most frequently reported human foodborne diseases were campylobacteriosis and salmonellosis. However, the most dangerous pathogens for humans were identified as foodborne pathogenic bacteria found in livestock products, including enterohaemorrhagic Escherichia coli (EHEC; O157:H7), Shigella sp., Enterococcus spp. or Listeria spp. Multidrug-resistant pathogens isolated from human outbreaks, cattle, swine, and poultry were most often $S$. aureus, Streptococcus spp., Vibrio sp. and Yersinia spp. [3,4]. According to Niu et al. [5], these bacteria can also be transmitted to food products by direct contact with animals or indirectly by vectors such as insects, rodents, wild birds, or irrigation water.

The global increase in multidrug-resistant infections and antibiotic failures in control of pathogens has raised concerns in human and veterinary medicine. An official report of the European Food Safety Authority (EFSA) regarding zoonotic and indicator bacteria isolated from humans, animals, and food showed that a high proportion $(28.6 \%)$ of human Salmonella strains were resistant to three or more antimicrobials, and $34.9 \%$ of E. coli strains isolated from pigs were resistant to more than six antibiotics [6]. 
There has been a marked increase in the antibiotic resistance of Gram-negative bacteria via a variety of mechanisms, such as antibiotic target modification, antibiotic degradation, and modulation of permeability through the bacterial membrane. These mechanisms have limited the development of novel antibiotics. The most resistant strains of bacteria are carbapenem-resistant Enterobacteriaceae, extensively drug-resistant (XDR) Pseudomonas aeruginosa, and XDR Acinetobacter baumannii. Understanding the mechanisms of resistance of multidrug-resistant bacteria is the main goal in the development of modern antibacterial agents [7].

Global livestock production is faced with an alarming increase in bacterial resistance, including among zoonotic pathogens. For example, Donkor et al., [8] showed higher antimicrobial resistance in livestock than in humans, with animal E. coli isolates exhibiting high levels of resistance to tetracycline and penicillin. This has led to renewed interest among scientists to develop alternative methods to antibiotics, including the use of bacteriophages, since the beginning of the 21st century [9].

Widespread multidrug resistance among bacteria necessitates the search for alternative methods of controlling infections, including pre- and probiotics, vaccines, bacteriophages, nanoparticles, antimicrobial peptides (AMPs) and others. An example is the use of bacteriophages to reduce or eliminate pathogenic bacteria in livestock production, as biocontrol agents to control foodborne pathogens and to reduce contamination on food-contact surfaces [9]. An important contribution to research on the use of bacteriophages to control bacteria, including zoonotic pathogens, is the development and implementation of new legal regulations in the EU regarding restrictions or complete bans on the use of selected groups of chemotherapeutics in individual sectors of animal production. An example of such legislative action is the EU Council Directive 2019/6 [10] coming into force in January 2022.

\subsection{General Characteristics of Bacteriophages}

Due to the widespread nature of bacteriophages (phages) associated with crops, live animals, and human intestinal environments, humans have direct and indirect contact with them. Many studies have demonstrated the common presence of bacteriophages in various fermented foods, such as yogurt and cheese. The application of specific bacteriophages to foods helps to reduce foodborne pathogenic bacteria [5].

Bacteriophages are bacterial viruses, causing complete lysis of a susceptible bacterial culture [11]. Interactions between phages and bacteria can be regarded as parasitism, as most virulent phage replication necessarily results in bacterial death. Certain interactions can be termed mutualistic, while some temperate phages encode benefits for the phenotypic properties of the host bacteria [12] According to Batinovic et al. [13], the prevalence of bacteriophages in the environment has been a natural phenomenon for billions of years, resulting in a balance of commensal and pathogenic bacteria. Phages and bacteria are the oldest and most ubiquitous microorganisms on Earth, likely having originated approximately 3 billion years ago [14,15].

Phages are prevalent in a variety of environments, including water, forest groundcover, food products, wastewater, and animal and human waste [16]. Bacteriophages have also been detected in commercial products, such as sera and human vaccines, as well as inside the human mouth (dental plaque and saliva) and in the gastrointestinal tracts of animals and humans [17].

Although bacteriophages may be present autonomously outside the host, all phages require the bacterial cell as a host for multiplication. Most phages are highly specific for host cell surface receptors such as receptor binding proteins (RBPs) or LPS [18,19].

\subsection{History of Bacteriophages}

Bacteriophages were first discovered more than 100 years ago by two microbiologists, Frederick Twort from England and the French Canadian Felix d'Herelle [20,21]. The first experimental and successful phage therapy was carried out by D'Herelle in the 
control of fowl typhoid in chickens (95-100\% survival) [22]. He also coined the term 'bacteriophage', meaning 'bacteria eater'. Finally, in 1940, electron microscopes were used to identify the viral nature and morphology of phages [23]. Bacteriophages have been used in various types of therapies in humans, e.g., in dermatological, ophthalmological, urological, paediatric, otolaryngology and surgical infections. The significant therapeutic success of these treatments had a major impact on the development of phage therapy in the pre-antibiotic era. This was crucial, as the only treatment available in the first two decades of the 20th century was serum therapy (e.g., for pneumococci or the diphtheria bacterium), so bacteriophage therapy began to dominate in human medicine [24].

The discovery of the antimicrobial properties of Penicillium notatum in 1928 by Alexander Fleming culminated in the successful development of the first major antibiotic, penicillin, in 1941 [25], which marked the beginning of the antibiotic era and naturally inhibited the development of bacteriophage therapy.

At present, as bacterial resistance to antibiotics is increasing significantly worldwide, phages are one of the factors with potential to replace them [26]. The best known bacteriophage centres in the world are the Eliava Institute of Bacteriophages, Microbiology, and Virology (EIBMV) of the Georgian Academy of Sciences, in Tbilisi, Georgia, and the Hirszfeld Institute of Immunology and Experimental Therapy (HIIET) of the Polish Academy of Sciences, in Wroclaw, Poland. Both institutes offer phage therapy against many bacterial and fungal pathogens, e.g., Staphylococcus spp., Klebsiella sp., Proteus sp., E. coli, and Pseudomonas sp., as well as other enteric pathogens [27-29].

\subsection{Classification of Bacteriophages}

Bacteriophages are the most widespread life forms on Earth. By 2018 year more than 650 strains of bacteriophages had been deposited in the American Type Culture Collection (ATCC) and >27,000 bacteriophage nucleotide sequences had been deposited in the International Nucleotide Sequence Database Collaboration (INSDC) [30]. The total number of these bacterial viruses has been estimated at $10^{32}$, which is 10 times the number of characterized bacteria. In water, the total count of bacteriophages has been estimated at $10^{4}$ to $10^{8}$ virions $/ \mathrm{mL}^{-1}$ [31].

The classification of bacteriophages is based on the type of nucleic acid (ssRNA, dsRNA, ssDNA, dsDNA), the structure of the capsid (e.g., helical, pleomorphic, icosahedral, filamentous/thread-like, complex/polyhedral), which is built of structural proteins, and their life cycle, bacterial target, and site (Figure 1). The phage taxonomy criteria applied by the International Committee on Taxonomy of Viruses (ICTV) were nucleic acid composition and virion morphology [9]. In 2015 the Bacterial and Archaeal Viruses Subcommittee (BAVS) classified phages into 873 species, 204 genera and 14 subfamilies [32]. The classification of bacteriophages is still ongoing, and in 2018 the ICTV presented a new classification of these bacterial viruses into 142 families, 81 subfamilies and 4978 species [9]. Most bacteriophages (96\%) belong to the order Caudovirales, which is grouped into three main families: Myoviridae, Podoviridae and Siphoviridae [32]. Most bacteriophages contain double-stranded DNA, and the nucleic acid is coated with a protein capsid. Some phages have an additional layer (envelope) [17]. As new bacteriophages are continually being detected, their classification is constantly modified. The latest classification of viruses, based on the virus taxonomy proposed by the ICTV, was presented in our previous paper [33]. 


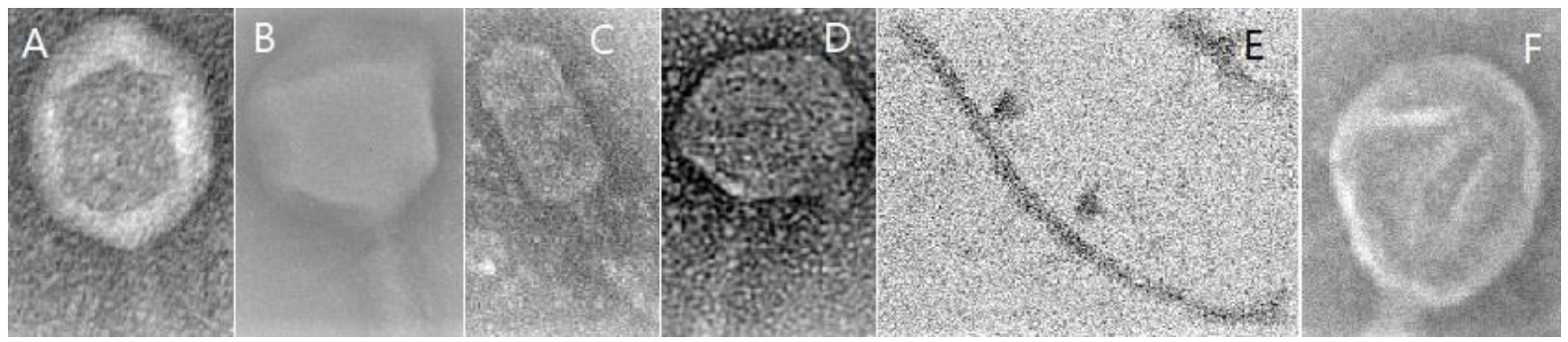

Figure 1. Examples of capsid structures in bacteriophages in TEM microscopy. (A) Helical; (B) Polyhedral; (C) Prolate; (D) Icosahedral; (E) Filamentous; (F) Pleomorphic-like.

\subsection{Life Cycles of Phages}

The life cycle of phages is an important element of infections of bacteria. Phages can be categorized into types based on their virulence: lytic (virulent, productive) and lysogenic (temperate, dormant). Virulent phages follow a lytic cycle in the bacterial cell and lyse it to release a newly created population of phages [34].

The lytic cycle includes the adsorption, penetration, biosynthesis, assembly and release of bacteriophages from the infected bacterium. During this process many phages use specific proteins located on the surface of the bacterial cell as receptors. During the adsorption phase, the bacteriophage adheres to the bacterial cell, and phage proteins bind to specific receptors, such as teichoic and lipoteichoic acid for Gram-positive bacteria or LPS for Gram-negative bacteria [35]. The next phase, penetration, consists of destruction of the bacterial wall by bacteriophage enzymes and insertion of the genetic material into the bacterial cell. This is followed by the formation of capsid structures for nucleic acid and protein replication, accompanied by inhibition of replication of bacterial DNA. The phage genetic material is transcribed in the bacterial cell by RNA polymerases to produce mRNA, which supresses host intracellular synthesis as a consequence of bacteriophage multiplication [36]. Tens, hundreds or thousands of replicated phages are released by means of lysis of the bacterial cytoplasmic membrane by a phage protein (holin) and the formation of pores by endolysin encoded by double-stranded phage DNA and peptidoglycan hydrolases. The duration of the entire lytic cycle may be $20-40 \mathrm{~min}$ or up to $1-2 \mathrm{~h}[9,37]$.

Lysogenic infection via phages involves integration of their genetic material into the chromosome of the infected bacteria (prophage), which does not destroy the bacterial cell or produce a new population of bacteriophages. It leads to the integration of the phage genetic material with the bacterial DNA and its transmission into a new population of bacteria. This kind of bacteriophage is called a temperate phage, and in cells carrying a prophage it is referred to as lysogenic. Nevertheless, the viral prophage, also called an endogenous phage (a latent form of phage), can become activated by abnormal environmental conditions and other external stress factors that can damage the bacterial genetic material, including sunlight, UV radiation, some alkylating cytostatics (chlorambucil, cyclophosphamide, ifosfamide, estramustine or chlormethine) or mutagenic antibiotics such as mitomycin C. In some cases, the prophage is excised incorrectly from the chromosome, taking with it neighbouring bacterial genes. This is one of the main means of horizontal gene transfer (HGT) among bacteria, which is also one of the main methods in molecular biology [9]. Phages which have been defined as temporary include E. coli Lambda [38], with activity against E. coli and other Enterobacteriaceae; phage Mu, specific for Salmonella, Citrobacter and Erwinia; MM1 Streptococcus pneumoniae; and $\varphi 11$ S. aureus [39].

In another type of life cycle involving chronic infection, bacteriophages infect the bacterial cell, in which new phage populations arise without destroying the bacteria. The chronic infection lifestyle is found in rod-shaped (filamentous) single-stranded DNA phages and in plasmaviruses that infect mycoplasmas. In the chronic infection lifestyle, phages are gradually eliminated from the bacteria over a long period without destruction of the cell [40]. 


\section{The Spectrum of Use of Bacteriophages}

The specificity of phage activity means that they infect only the bacteria specific for them (called the host) via external receptors, which determines the phage host range. Therefore, the use of phage therapy relies on a detailed and accurate characterization of the bacteria, including pathotypes and serotypes. Bacteriophages can be used in a variety of forms and methods to control and eliminate bacteria, including therapy, food protection and sanitation procedures [1,9]. Examples of the scope of the use of bacteriophages are presented in Table 1.

Table 1. Examples of the use of bacteriophages in controlling bacteria.

\begin{tabular}{|c|c|c|c|}
\hline Scope of Use & Example & Host Pathogens & References \\
\hline $\begin{array}{l}\text { Treatment of human and } \\
\text { animals }\end{array}$ & $\begin{array}{c}\text { Gastroenteric, respiratory, urinary } \\
\text { tract and skin infections, otitis, } \\
\text { keratitis }\end{array}$ & $\begin{array}{l}\text { E. coli, Salmonella spp., S. aureus, } \\
\text { Pseudomonas spp., Enterococcus spp., } \\
\text { Acinetobacter baumanni }\end{array}$ & {$[1]$} \\
\hline \multirow{3}{*}{ Prophylaxis and treatment } & $\begin{array}{c}\text { Neonatal diarrhoeal infections in } \\
\text { calves; }\end{array}$ & E. coli, & [41] \\
\hline & $\begin{array}{c}\text { Campylobacter infections in broiler } \\
\text { chickens; }\end{array}$ & Campylobacter jejuni & {$[42]$} \\
\hline & Salmonella infections in chickens & Salmonella spp. & [43] \\
\hline Decontaminants & $\begin{array}{l}\text { Biocontrol agents against food- and } \\
\text { beverage-borne pathogens }\end{array}$ & $\begin{array}{l}\text { Control of LAB growth during } \\
\text { ethanol fermentation }\end{array}$ & {$[44,45]$} \\
\hline Biosanitization & $\begin{array}{l}\text { On equipment surfaces to eradicate } \\
\text { biofilms in food production; on } \\
\text { plastic, glass, and ceramic surfaces } \\
\text { in hospitals }\end{array}$ & $\begin{array}{c}\text { S. aureus, E. coli, } P \text {. aeruginosa, } L . \\
\text { monocytogenes Acinetobacter } \\
\text { baumannii }\end{array}$ & {$[46,47]$} \\
\hline Bio-preservation & $\begin{array}{l}\text { Highly processed products with a } \\
\text { short shelf life }\end{array}$ & $\begin{array}{l}\text { Listeria monocytogenes; Campylobacter } \\
\text { spp. }\end{array}$ & [48] \\
\hline Agriculture & $\begin{array}{l}\text { Biocontrol of plant pathogens, i.e., } \\
\text { potato and tomato diseases; onion } \\
\text { scab; lettuce and leek diseases; fruit } \\
\text { tree diseases; cultivated mushrooms }\end{array}$ & $\begin{array}{c}\text { Pseudomonas spp., Xanthomonas spp., } \\
\text { Erwinia spp., Ralstonia spp., } \\
\text { Agrobacterium spp., Xylella spp., } \\
\text { Pectobacterium spp., Dickeya spp. } \\
\text { Pleurotus ostreatus }\end{array}$ & [49] \\
\hline Aquaculture & $\begin{array}{l}\text { Biocontrol of fish pathogens in } \\
\text { commercial fish farming }\end{array}$ & $\begin{array}{l}\text { Mainly to Vibrio spp., less to } \\
\text { Edwardsiella spp., Lactococcus spp., } \\
\text { Pseudomonas spp., Aeromonas spp., } \\
\text { Flavobacterium spp. }\end{array}$ & [49] \\
\hline
\end{tabular}

Bacteriophages can potentially be used as biological control agents, especially in the reduction and elimination of bacterial contamination in foods, e.g., by Salmonella, Listeria monocytogenes, Campylobacter spp. or E. coli O157:H7 [15,50]. The high efficacy and safety of bacteriophage therapy is due in part to their specificity for selected bacteria: a single species, serotype, or strain. This is beneficial because the commensal gut microbiota is not destroyed. Another advantage is that, due to the self-replication of bacteriophages at the site of application, repetition of the application is often unnecessary. In many cases, no side effects of clinical treatment are observed, indicating a high level of safety that has been confirmed in many studies [51]. However, the application of bacteriophages in live animals or humans induces a cellular immune response, which could lead to the inactivation of phages, rendering them ineffective in eliminating bacteria [52-54].

In many experimental phage therapies a beneficial effect was observed as a significant reduction in bacterial content or elimination of the pathogens. Phages have been used to control Shiga-toxin-producing E. coli (ETEC) infections in newborn ruminants, including calves and lambs, or other livestock species, such as piglets [41,55]. They have been exploited to control bacterial infections in humans in many countries, including Poland, Georgia, Russia, France, Belgium, Switzerland and the USA [56-58]. Phage therapies have 
been applied against infections caused by numerous pathogens, especially multidrugresistant bacteria, e.g., Acinetobacter, Burkholderia, Citrobacter, Enterobacter, Enterococcus, Escherichia coli, Klebsiella, Morganella, Proteus, Pseudomonas, Shigella spp., Shigella flexneri, Staphylococcus, Salmonella, Serratia and Stenotrophomonas. According to the Eliava Phage Therapy Centre, bacteriophage therapy against Enterococcus faecalis, E. coli (O11, O18, O20, O25, O26, O44, O55, O113, O125 and O128), Proteus vulgaris, Proteus mirabilis, Pseudomonas aeruginosa, Salmonella spp., and Shigella spp. showed positive results in $35-50 \%$ of human patients $[59,60]$.

\section{Bacteriophage Interactions during Phage Therapy}

Bacteriophages are regarded as the most applicable ecological and alternative means of elimination of pathogens (control and prevention of infections) due to their natural origin and numerous advantages, including the following:

- lysis of bacteria usually highly resistant to antibiotic therapy, living in a biofilm;

- high degree of safety for commensal and symbiotic flora;

- possibility of use with other bacteriophages as a cocktail or with other antibacterials;

- complete biodegradability of bacteriophages, making them safe for the organism and the environment [17].

However, phage therapy may carry a risk of immunological reactions, which is linked to the protein structures of bacteriophages. The immune response to bacteriophages depends on the location of the bacterial infection and the route of administration of the phages. The activity of bacteriophages also relies on their ability to penetrate epithelial cells and potentially spread to the bloodstream, lymph and internal organs such as the lung, liver, kidney and brain [61]. Bacteriophages can activate dendritic cells to synthesize pro-inflammatory factors (including IL-6, IL- $1 \alpha$, IL-1 $\beta$ and TNF- $\alpha$ ) and to induce changes in the expression profile of these cell surface proteins and activation of the NF- $\mathrm{kB}$ signalling pathway [62].

The results of many studies confirm that bacteriophages can be phagocytosed by mammalian cells [63]. For example, Geier et al. [64] demonstrated rapid removal of wild-type phage $\lambda$ from the circulatory system in humans. According to the authors, phagocytosis via immune cells is the main process of elimination of bacteriophages in mammals, and this mechanism takes place during lysis of bacteria by bacteriophages, which increases the activity of phagocytic cells, including PMN cells. The higher number of neutrophils at the site of infection is necessary to remove phage-resistant bacteria; this neutrophil-phage cooperation process has been confirmed in the resolution of $P$. aeruginosa infections $[53,65]$. However, some studies [66] have confirmed that bacteriophages can also express anti-inflammatory properties by decreasing the expression of TNF $\alpha$ and monocyte chemoattractant protein-1, which reduces ROS production by neutrophils and protects the epithelia against damage.

Some bacteriophages can also be a natural component of the intestinal microbiota and consumed food [67]. The oral administration of phages against Staphylococcus, Klebsiella, Escherichia, Proteus and Pseudomonas also induces the production of antibodies [68]. There has been no evidence of immunological disorders following phage ingestion per os at any concentration [69]. Topical application of phages to animals and humans also caused no side effects [70].

Minor problems have been observed in the case of other internal organs and blood vessels, which are not natural environments for phages. Here the immunogenic and immunomodulatory effects of phages can be observed. Bacteriophages can have non-specific effects on the immunological functions of various immune cells, including PMNCs, as well as on cytokine production and the induction of specific antibodies against non-phage antigens [71]. For example, resident liver macrophages (also called Kupffer cells) are able to eliminate bacteriophages by phagocytosis four times faster than spleen macrophages. The natural innate immune response is usually sufficient to eliminate pathogens before the activation of adaptive immune mechanisms. Bacteriophages can activate immune 
mechanisms and thus affect the metabolic activity of immune cells. However, bacteriophages can inhibit the production and release of reactive oxygen species in response to pathogens, which could decrease innate antibacterial immunity. [72]. Phages can induce antibodies that neutralize them, which can inhibit the antibacterial effect of phages in the form of lysis of targeted bacteria [71,73]. It is not currently clear how long this type of antibody will remain in the body, as knowledge of the kinetic aspect of bacteriophage activity is insufficient. Moreover, the titre of these antibodies depends on many factors, including the route of application (local application causes a minor increase in antibodies) and its frequency [74]. Some information about the influence of bacteriophages on immune responses in animal's model has been presented in Table 2.

Table 2. Examples of the influence of bacteriophages on immune responses in animals.

\begin{tabular}{|c|c|c|c|c|}
\hline Kind of Phage & Form of Application & Animal Model & Influence on Immune Parameters & References \\
\hline $\begin{array}{l}\text { Pseudomonas spp. bacteriophage } \\
\text { (PA1Ø) }\end{array}$ & $\begin{array}{l}100 \mu \mathrm{L} \text { of PA1 } \varnothing\left(5 \times 10^{4} \mathrm{PFU} ; 5 \times\right. \\
10^{7} \mathrm{PFU}(10 \mathrm{MOI}) \text { or } 5 \times 10^{8} \mathrm{PFU} \\
(100 \mathrm{MOI}) \text { in a single i.p. dose }\end{array}$ & $\begin{array}{l}\text { 4-5-week-old male ICR mice } \\
\text { weighing } 24-26 \mathrm{~g}\end{array}$ & $\begin{array}{c}\text { Increase in phagocytosis (killing } \\
\text { effect of PA1 } \varnothing+\text { PMN up to } 6 \mathrm{~h} \\
\text { after application) }\end{array}$ & [65] \\
\hline $\begin{array}{c}\text { Pseudomonas aeruginosa phage } \\
\text { PAK_P1 }\end{array}$ & $\begin{array}{l}\text { Intranasally at a curative dose of } \\
1.0 \times 10^{8} \mathrm{PFU} \text { or } 1.0 \times 10^{9} \mathrm{PFU}\end{array}$ & $\begin{array}{c}\text { Wild-type BALB/c (C), wild-type } \\
\text { C57B16/J (B6) }\end{array}$ & $\begin{array}{l}\text { Increase in neutrophil activity, NK } \\
\text { cells; reduced production of IFN } \gamma \\
\text { and TNF } \alpha\end{array}$ & [75] \\
\hline Cronobacter sakazakii ES2 phage & $\begin{array}{l}\text { Phage suspension } 10^{6} \mathrm{PFU} \cdot \mathrm{mL}^{-1} \\
\text { in vitro }\end{array}$ & 6-8-week-old C57BL/ 6 mice & $\begin{array}{c}\text { Increase in expression of } \\
\text { maturation markers CD86, CD40, } \\
\text { and MHC II; } \\
\text { stimulation of induction of } \\
\text { NF- } \kappa \text { Bp65-mediated-IL-12p40; } \\
\text { stimulation of IL-12 expression; } \\
\text { suppression of IL-6, TNF- } \alpha, \text { IL-1 } \beta \text {, } \\
\text { and IFN- } \gamma\end{array}$ & {$[62]$} \\
\hline E. coli $\mathrm{T} 4$ phage & $\begin{array}{c}\text { Intraperitoneal injection at } 20 \\
\mu \mathrm{g} / \text { mouse }\end{array}$ & $\begin{array}{l}\text { Female C57Bl6/J (6-8-week-old) } \\
\text { mice }\end{array}$ & $\begin{array}{l}\text { No effect on production of } \\
\text { cytokines IL- } 1 \alpha, \text { IL- } 6 \text {, IL-12, and } \\
\text { TNF- } \alpha \text {; minor changes in } \\
\text { expression } \\
\text { of MHC II, CD } 40, \text { CD86, and CD80 }\end{array}$ & {$[76]$} \\
\hline E.coli $\mathrm{T} 4$ bacteriophages & T4 phages $5 \times 10^{8} \mathrm{PFU} / \mathrm{mL}$ & $\begin{array}{l}\text { 8-12-week-old female C57BL/6 } \\
\text { mice }\end{array}$ & $\begin{array}{l}\text { Inhibition of specific antibody } \\
\text { response; reduction in } \\
\text { bacteria-induced ROS production } \\
\text { by phagocytic cells; antitumour } \\
\text { response; activation of T cells for } \\
\text { IFN- } \gamma \text { production }\end{array}$ & [77] \\
\hline E. coli $\mathrm{P} 1$ and $\mathrm{P} 2$ phages & $10^{6} \mathrm{PFU} / \mathrm{mL}$ in vitro & Mice & $\begin{array}{l}\text { Stimulation of TNF } \alpha \text {; stimulation } \\
\text { of macrophage activity in vitro }\end{array}$ & [78] \\
\hline Wild-type E. coli $\mathrm{T} 7$ phage & $\begin{array}{l}10^{9} \mathrm{PFU} / \mathrm{mL} \text { injected in vitro into } \\
\text { tail vein of mice }\end{array}$ & $\begin{array}{c}\text { Adult female C57BL/6J, SCID } \\
\text { (C57BL/6J-Prkdcscid), } \\
\text { B-cell-deficient } \\
\text { (C57BL/10-Igh-6tm1Cgn) and } \\
\text { T-cell deficient } \\
\text { (C57BL/6J-Hfh11nu) mice }\end{array}$ & $\begin{array}{l}\text { Spontaneous antibodies, mainly } \\
\text { IgM, observed in sera; slight effect } \\
\text { on NK activation; } \\
\text { anti-inflammatory effect-ROS } \\
\text { suppression }\end{array}$ & [79] \\
\hline Wild-type E.coli $\varphi 26, \varphi 27, \varphi 29$ & $\begin{array}{l}10^{7}-10^{8} \mathrm{PFU} / \mathrm{mL} \text { for } 5 \text { days per } \\
\text { rectum as suppositories }\end{array}$ & $\begin{array}{c}25 \text { newborn HF calves aged } 1 \mathrm{~d} \text { to } \\
2 \text { weeks }\end{array}$ & $\begin{array}{l}\text { Significant increase in IgG and IgA } \\
\text { production stimulation of } \\
\text { nonspecific immune } \\
\text { response-IFN } \gamma, \text { lysozyme; } \\
\text { activation of acute phase response } \\
\text { SAA and HP }\end{array}$ & [41] \\
\hline $\begin{array}{l}\text { Wild-type E.coli phage and } \\
\text { bacteriophage genomes NC-A: } \\
\text { MK310182; NC-B: MK310183; } \\
\text { NC-G: MK310184 }\end{array}$ & $\begin{array}{c}3 \times 10^{7} \mathrm{PFU} / \mathrm{mL} \text { of phage mixture } \\
\text { with drinking water }\end{array}$ & $\begin{array}{l}\text { 8-week-old germ-free Swiss } \\
\text { Webster mice }\end{array}$ & $\begin{array}{l}\text { Whole bacteriophages and phage } \\
\text { DNA stimulated IFN- } \gamma \text { via } \\
\text { nucleotide-sensing receptor TLR9 }\end{array}$ & {$[80]$} \\
\hline S. aureus vB_SauM_JS25 phage & $\begin{array}{l}\text { MAC-T cells pre-treated with } \\
\text { vB_SauM_JS25 phage } 10^{8} \\
\text { PFU/well for } 3 \mathrm{~h}\end{array}$ & $\begin{array}{l}\text { In vitro MAC-T bovine mammary } \\
\text { epithelial cells }\end{array}$ & $\begin{array}{l}\text { Reduction in TNF- } \alpha, \text { IL- } 1 \beta \text {, IL-6, } \\
\text { IL-8, and IL-10 }\end{array}$ & [54] \\
\hline $\begin{array}{c}\text { Staphylococcus spp. bacteriophage } \\
\text { A3R or } 676 Z\end{array}$ & $\begin{array}{l}3 \text { doses of } 10^{10} \mathrm{PFU} / \text { mouse in } \\
\text { drinking water and peritoneally }\end{array}$ & C57BL/6J normal male mice & $\begin{array}{l}\text { Induction of specific antibodies in } \\
\text { blood (IgM, IgG, IgA) }\end{array}$ & [81] \\
\hline $\begin{array}{c}\text { Klebsiella pneumoniae MTCC109 } \\
\text { bacteriophage PA43 }\end{array}$ & $\begin{array}{l}\text { Intranasal application of } 10^{9} \mathrm{PFU} \\
\text { BPA43 phage after } 2 \mathrm{~h} \text { of bacterial } \\
\text { infection }\end{array}$ & $\begin{array}{l}\text { BALB/c mice, } 6-8 \text { weeks old, } \\
\text { weight } 20-25 \mathrm{~g}\end{array}$ & $\begin{array}{c}\text { Suppression of local inflammatory } \\
\text { reaction in lungs; suppression of } \\
\text { migration of lymphocytes and } \\
\text { macrophages }\end{array}$ & [82] \\
\hline
\end{tabular}

Antiphage antibodies are probably one of the most important factors influencing the efficacy of phage therapy. However, the activation of the production of neutralizing 
antibodies by phages need not be a problem during the initial phase of treatment of bacterial infections, because bacteriophage activity is much faster than the production of phage-neutralizing antibodies [27]. However, these antibodies can affect the efficacy of treatment during the second phase of therapy. This necessitates the implementation of additional solutions, such as the following:

- repeating phage administration two or more times, because bacteriophages can multiply at the site of application during infection of the host bacteria;

- increasing the phage concentration in the solution, because a high level of phages protects against complete destruction by neutralizing antibodies;

- $\quad$ using different phages, especially during the second and subsequent cycles of application during treatment, because resistance differs from one phage to another [27]. In addition to the increase in neutralizing antibodies during phage therapies, the concentration of class $\mathrm{M}$ and $\mathrm{G}$ immunoglobulins increases as well and continues to increase with subsequent applications of phage preparations [83,84].

Besides activating humoral response mechanisms, phages also play a significant role in the modulation of cellular immunity against them. For example, s.c. application of MS-2 phages induced a hypersensitivity reaction in guinea pigs [85]. It has been suggested that the cellular response plays only a minor role in phage inactivation, as observed in the case of phage T7 in T cell-deficient mice [79]. In another study [86], phages had an immunosuppressive effect by suppressing the activation of $\mathrm{T}$ lymphocytes during the development of transplantation tolerance.

While bacteriophage therapies have been an effective tool in control of bacterial infections in various animal species, phages are also currently used for typing and diagnosis of specific bacterial species and for control of foodborne pathogens in food.

\section{Commercial Products with Bacteriophages for Elimination of Foodborne Zoonotic Pathogens}

Foodborne infections are the most important global health problem, contributing significantly to hospitalizations and deaths worldwide despite many advances in pathogen surveillance. Traditional food sanitation techniques using antimicrobial methods (including pasteurization, high pressure, irradiation or chemical treatment) can reduce pathogens in foods in varying degrees. However, these methods may damage equipment and adversely affect the organoleptic qualities (and possibly the nutritional value) of foods. The most important problem with using chemicals is that they eliminate 'good' microbes, which are beneficial in natural preservation of foods [87]. Therefore, it seems preferable to use an effective natural and ecological alternative such as bacteriophages for biocontrol of foodborne pathogens. Bacteriophages are mainly used in three sectors of the food industry to ensure food safety: primary production, biopreservation and biosanitization. As components of commercial products, they are currently finding application in the elimination of pathogens from food products of animal origin (meat products, milk and dairy products) or plant origin (fresh fruits and vegetables).

The number of commercial bacteriophage products approved for use in food safety in various countries is continually increasing. Many commercial companies around the world have shown interest in information about the use of bacteriophages as antibacterial tools to control foodborne pathogens, e.g., in the United States (AmpliPhi Biosciences (VI, USA), Enbiotix (Boston, MA, USA); Intralytix), the United Kingdom (Novolytics, Sarum Biosciences and Fixed Phage, Bolton, UK), EU countries such as France (Pherecydes Pharma, Romainville, Ile-de-France, France) and Portugal (Technophage and InnoPhage, Lisbon, Portugal), and other countries [88]. Detailed information about commercial bacteriophage products used for biocontrol of foodborne pathogens in food is presented in Table 3. 
Table 3. Examples of commercial bacteriophage products used in biocontrol of foodborne pathogens in various foods.

\begin{tabular}{|c|c|c|c|c|c|}
\hline $\begin{array}{l}\text { Commercial Phage } \\
\text { Product }\end{array}$ & Target Bacteria & Company & Target Food Products & $\begin{array}{c}\text { Country Approving } \\
\text { Product }\end{array}$ & References \\
\hline SalmoLyse ${ }^{\circledR}$ & Salmonella spp. & Intralytix, Inc., USA & $\begin{array}{l}\text { Raw pet food ingredients; } \\
\text { meat products: chicken, } \\
\text { tuna, turkey; plant products: } \\
\text { cantaloupe, lettuce }\end{array}$ & USA & [89] \\
\hline SalmoFreshTM & Salmonella spp. & Intralytix Inc., USA & $\begin{array}{l}\text { Poultry, fish and shellfish, } \\
\text { fresh and processed fruits } \\
\text { and vegetables }\end{array}$ & USA, Canada, Israel & [90] \\
\hline $\begin{array}{l}\text { PhageGuard S } \\
\text { SalmonelexTM }\end{array}$ & Salmonella spp. & $\begin{array}{l}\text { Micreos Food } \\
\text { Safety/Nederlands }\end{array}$ & Fresh poultry meat & $\begin{array}{l}\text { USA, Canada, Australia, } \\
\text { Israel }\end{array}$ & [91] \\
\hline Bafasal $^{\circledR}$ & $\begin{array}{c}\text { Salmonella spp., } \\
\text { Aeromonas spp. Pseudomonas } \\
\text { spp., Yersinia spp. }\end{array}$ & $\begin{array}{l}\text { Proteon Pharmaceuticals } \\
\text { (Łódź, Poland) }\end{array}$ & $\begin{array}{l}\text { Regulatory-approved } \\
\text { poultry feed }\end{array}$ & Poland & [9] \\
\hline EnkoPhagum & $\begin{array}{c}\text { Salmonella spp., Shigella spp.; } \\
\text { enteropathogenic E. coli; } \\
\text { Staphylococcus spp. }\end{array}$ & $\begin{array}{l}\text { Brimrose Technology } \\
\text { Corporation (Sparks } \\
\text { Glencoe, MD, USA) }\end{array}$ & Meat products & Georgia & [92] \\
\hline BacWash TM & Salmonella spp. & $\begin{array}{l}\text { OmniLytics Inc. (Sandy, UT, } \\
\text { USA) }\end{array}$ & $\begin{array}{l}\text { For disinfection of skin of } \\
\text { live animals prior to } \\
\text { slaughter }\end{array}$ & USA & [4] \\
\hline Biotector $^{\circledR} \mathrm{S}$ & $\begin{array}{l}\text { Salmonella Gallinarum } \\
\text { S. Pullorum }\end{array}$ & $\begin{array}{l}\text { CJ CheilJedang Research } \\
\text { Institute of Biotechnology } \\
\text { (Seoul, Korea) }\end{array}$ & $\begin{array}{l}\text { In animal feed to control } \\
\text { Salmonella in poultry }\end{array}$ & South Korea & [93] \\
\hline PhageGuard STM & Salmonella & $\begin{array}{l}\text { Micreos Food Safety BV } \\
\text { (Wageningen, The } \\
\text { Netherlands) }\end{array}$ & Fresh poultry meat & $\begin{array}{c}\text { Netherlands, Australia, } \\
\text { Canada, USA }\end{array}$ & {$[87,94]$} \\
\hline EcoShield TM & Escherichia coli O157:H7 & $\begin{array}{l}\text { Intralytix Inc. (Columbia, } \\
\text { MD, USA) }\end{array}$ & $\begin{array}{c}\text { Kosher meat (ground beef); } \\
\text { vegetables (tomatoes, } \\
\text { broccoli, spinach); lettuce } \\
\text { and cantaloupe; leafy greens }\end{array}$ & USA & {$[9,91,95]$} \\
\hline Secure Shield E1 & Escherichia coli O157:H7 & $\begin{array}{l}\text { FINK TEC GmbH (Hamm, } \\
\text { Germany) }\end{array}$ & Beef carcasses & USA & [96] \\
\hline EcoShield PX ${ }^{\mathrm{TM}}$ & Stx Escherichia coli O157:H7 & $\begin{array}{c}\text { Intralytix, Inc., Baltimore, } \\
\text { MD, USA }\end{array}$ & $\begin{array}{l}\text { Fresh-cut leafy greens; foods } \\
\text { of plant origin, beef, chicken }\end{array}$ & USA, Canada, Israel & {$[90,95]$} \\
\hline $\begin{array}{l}\text { ShigaShield } \\
\text { (ShigActive }^{\mathrm{TM}} \text { ) }\end{array}$ & Shigella spp. & $\begin{array}{c}\text { Intralytix, Inc., Baltimore, } \\
\text { MD, USA }\end{array}$ & $\begin{array}{l}\text { Beef, poultry, dairy products, } \\
\text { including cheese; fruit and } \\
\text { vegetable surfaces }\end{array}$ & USA & {$[90,97]$} \\
\hline ListShield $^{\mathrm{TM}}$ & Listeria monocytogenes & $\begin{array}{c}\text { Intralytix, Inc., Baltimore, } \\
\text { MD, USA }\end{array}$ & $\begin{array}{l}\text { Food biopreservative in } \\
\text { meat and poultry products }\end{array}$ & USA, Canada, Israel & {$[9,87,90]$} \\
\hline $\begin{array}{l}\text { Listex P100 } \\
\text { PhageGuard } \\
\text { Listex }^{\mathrm{TM}}\end{array}$ & Listeria monocytogenes & $\begin{array}{c}\text { Micreos Food Safety, } \\
\text { Wageningen, Netherlands }\end{array}$ & $\begin{array}{l}\text { Beef and turkey meat; fish } \\
\text { and shellfish; dairy products; } \\
\text { red smear soft cheese, } \\
\text { smoked salmon and fresh } \\
\text { salmon; frozen vegetables }\end{array}$ & $\begin{array}{l}\text { USA, Australia, New } \\
\text { Zealand, Israel, } \\
\text { Switzerland, the } \\
\text { Netherlands }\end{array}$ & {$[87,98]$} \\
\hline ListPhage $^{\mathrm{TM}}$ & Listeria monocytogenes & $\begin{array}{c}\text { Intralytix, Inc., Baltimore, } \\
\text { MD, USA }\end{array}$ & Pet food & USA, EU & [91] \\
\hline Agriphage $^{\mathrm{TM}}$ & $\begin{array}{l}\text { Xanthomonas campestris pv. } \\
\text { vesicatoria, Pseudomonas } \\
\text { syringae pv. tomato }\end{array}$ & OmniLytics Inc., USA & $\begin{array}{l}\text { Foods of plant origin, } \\
\text { especially tomatoes and } \\
\text { peppers }\end{array}$ & USA & [91] \\
\hline Agriphage-Fire Blight & Erwinia amylovora & OmniLytics Inc., USA & Surfaces of apples and pears & USA & [91] \\
\hline Biolyse $^{\mathrm{TM}}$ & $\begin{array}{c}\text { Erwinia, Pectobacterium, } \\
\text { Pseudomonas }\end{array}$ & $\begin{array}{l}\text { APS Biocontrol } \\
\text { Ltd./Dundee, UK }\end{array}$ & $\begin{array}{l}\text { Vegetables, including } \\
\text { potatoes }\end{array}$ & UK, Europe & [91] \\
\hline
\end{tabular}

\section{Advantages and Disadvantages of Bacteriophage Therapy}

Phages have several advantages over antibiotics as therapeutic agents, such as activity against all types of bacteria, including MDR-pathogens. Their narrow antibacterial spectrum (which protects the natural microbiome), the low level of side effects, and their extensive distribution when administered systemically are also worth noting. They also may exert an effect on the inflammatory response, and their low production cost and high efficacy are significant benefits $[31,99]$. Many studies have confirmed the beneficial effects of the use of bacteriophages, shown as follows:

Bacteriophages show high specificity for their target pathogens and kill only pathogens without destroying the physiological saprophytic flora; the narrow host range of phages is also a useful feature in prophylaxis of infections caused by enteric bacteria [100]. 
The distribution of phages in the body following systemic administration is much more extensive than in the case of antibiotics, in part due to the lack of or very low level of resistance of bacteria [31].

- Because the mechanism of action of phages against the host bacteria is different to that of antibiotics, they are highly effective against many pathogens, especially against multidrug-resistant bacteria [36].

- Phages replicate at the site of infection even after a single application, because they multiply inside the bacterial cell and therefore are released at the site of infection [101].

- $\quad$ Bacteriophages are resistant to stress factors during food production [91].

- Phage therapy is theoretically cheaper than antibiotic therapy due to the simplicity of production [99]. The unit costs of production as well as the costs of isolation and characterization are comparable or even lower than the costs of classical chemotherapeutic products [102].

- There is no withdrawal period in livestock due to the lack of residue in tissues as soon as therapy is completed [103].

- $\quad$ There are no side effects or allergic reactions because most bacteriophages consist mainly of proteins and genetic material (DNA or RNA).

However, in addition to the positive effects of phage therapies, widespread use of bacteriophages is limited by obstacles such as the following:

- Due to their high specificity for a single type of bacteria, bacteriophages have a narrow host range [104].

- Bacteriophages may neutralize antibodies, which may prevent a portion of the administered phage dose from adhering to the target bacteria [104].

- $\quad$ Bacteriophages have poor stability in the environment, e.g., sunlight, UV, low $\mathrm{pH}<3.5$, or high temperature $>50^{\circ} \mathrm{C}[17,105]$.

- $\quad$ Only lytic phages are admissible in phage therapy because lysogenic (temporary) phages may be a source of horizontal transfer of bacterial toxins or antibiotic resistance [31].

- The duration of survival of phages is varied, depending in part on the presence of the host bacteria. Their activity is also influenced by the environment within the organism in which it is administered, and therefore the survival of phages must be monitored at the site of administration in order to assess their antimicrobial activity [99].

- Information about the kinetics of phages remains insufficient, especially the degree of adsorption, the number of replications necessary for a therapeutic effect, the latent period, and their elimination from the body by phagocytic cells [106].

\section{Bacteriophage Efficacy in Experimental Models}

There are many methods of application of phages in therapies for humans and animals, including intraperitoneal, subcutaneous or intramuscular injection or oral, intragastric, rectal, topical or intranasal administration. Forms of administration of phages during therapy include sprays, aerosols, lozenges, compresses, mouthwash, suppositories, throat rinses, bandages, eye or ear drops and tampons [107]. In many studies in humans and animals, the form of application and type of administration has been associated with the type and location of the disease. In earlier studies [108-111], the best therapeutic effect was observed after direct application of phages to the target bacteria, as in the case of bacterial dysentery caused by Shigella; intestinal dysbacteriosis caused by E. coli and Proteus spp.; lung and pleural infections caused by Staphylococcus; suppurative skin infections caused by Pseudomonas, Staphylococcus, Klebsiella, Proteus, and E. coli; and infections of the skin or nasal mucosa caused by Klebsiella spp.

Some studies have explored the use of phages for control and treatment of neonatal enterotoxigenic E. coli infections in cattle, poultry and pigs $[40,112]$. Bacteriophages have also been used in controlling systemic infections with foodborne pathogens, including Salmonella spp., E. coli, Campylobacter spp., Vibro spp., Pseudomonas aeruginosa, and other pathogens, such as Staphylococcus spp., Streptococcus spp., Klebsiella spp., Acinetobacter spp., 
and even Mycobacterium spp. These experiments were carried out in experimental mouse or rat models, as well as in chickens, rabbits, calves, pigs and sheep. Examples of the effects of experimental phage therapies in different animal species and in the control of various pathogens are presented in Table 4.

Table 4. Examples of major experimental studies on phage therapy in animals.

\begin{tabular}{|c|c|c|c|c|c|}
\hline Animal Species & Pathogen Species & Phage Treatment & Results & Treatment Procedure & References \\
\hline $\begin{array}{c}\text { Cattle-newborn } \\
\text { Holstein-Friesian heifers }\end{array}$ & $\begin{array}{l}\text { E. coli O9:K30.99 } 10^{6} \\
\text { CFU mL }\end{array}$ & $\begin{array}{l}\text { Oral administration of phage } \\
\text { cocktail (B44/1 and B44/2), } \\
10^{11} \mathrm{PFU} \mathrm{mL}^{-1}\end{array}$ & $\begin{array}{c}100 \% \text { reduction of mortality } \\
\text { in calves; } \\
\text { Significant reduction }(93 \%) \\
\text { of morbidity of bacterial } \\
\text { diarrhoea; } \\
\text { high protection against } \\
\text { ETEC infections }\end{array}$ & Treatment of diarrhoea & [113] \\
\hline $\begin{array}{l}\text { Cattle-Holstein-Friesian } \\
\text { dairy cows }\end{array}$ & $\begin{array}{l}\text { Staphylococcus } \\
\text { aureus }\end{array}$ & $\begin{array}{l}\text { Direct infusions into teats } \\
\text { with bacteriophage K } \\
\text { cocktail (CS1, DW2) } \\
\left(10^{8} \mathrm{PFU} \mathrm{ml}^{-1}\right)\end{array}$ & $\begin{array}{l}\text { About } 10,000 \text {-fold reduction } \\
\text { of } S \text {. aureus in udder; } \\
\text { lower presence of somatic } \\
\text { cells in milk }\end{array}$ & $\begin{array}{l}\text { Treatment of subclinical } \\
\text { mastitis }\end{array}$ & [114] \\
\hline $\begin{array}{l}20 \text { female BALB/cJRj (SPF) } \\
\text { mice }\end{array}$ & $\begin{array}{c}\text { Staphylococcus aureus } \\
\text { causing mastitis in cows }\end{array}$ & $\begin{array}{l}\text { Inoculation with } 10^{8} \text { PFU of } \\
\text { ISP phage mixture into } \\
\text { mammary glands }\end{array}$ & $\begin{array}{l}\text { Significant reduction of } \\
\text { bacterial count; reduction or } \\
\text { lack of clinical changes in } \\
\text { mammary glands }\end{array}$ & $\begin{array}{l}\text { Antibacterial activity } \\
\text { and therapeutic effect }\end{array}$ & [115] \\
\hline $\begin{array}{l}280 \text { Holstein-Friesian } \\
\text { lactating cows with } \\
\text { metritis during the first and } \\
\text { second lactations }\end{array}$ & $\begin{array}{l}\text { Escherichia coli strains } \\
\text { causing metritis }\end{array}$ & $\begin{array}{l}\text { Intravaginal administration } \\
\text { of } 20 \mathrm{~mL} 10 \text {-phage cocktail } \\
10^{9} \mathrm{PFU} \mathrm{mL} \mathrm{mL}^{-1} \text { at } 230,260 \\
\text { and } 275 \text { days of gestation }\end{array}$ & $\begin{array}{l}\text { Lack of antibacterial effect; } \\
\text { no prophylactic effect } \\
\text { in prevention of metritis; } \\
\text { increased incidence of } \\
\text { retained placenta }\end{array}$ & $\begin{array}{l}\text { Failure of therapeutic } \\
\text { and prophylactic effect } \\
\text { in metritis }\end{array}$ & [116] \\
\hline $\begin{array}{l}25 \text { newborn } \\
\text { Holstein-Friesian heifers } \\
\text { aged 0-14 days old }\end{array}$ & $\begin{array}{l}\text { E. coli causing diarrhoea } \\
\text { in newborn calves }\end{array}$ & 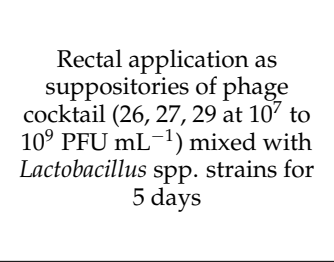 & $\begin{array}{l}\text { Significant reduction of } \\
\text { clinical signs and duration of } \\
\text { diarrhoea <24h; significant } \\
\text { reduction of ETEC content in } \\
\text { faeces } 2 \log _{10} \mathrm{CFU} / \mathrm{mL} \text {; } \\
\text { protection against } \\
\text { re-infection for } 3 \text { weeks after } \\
\text { treatment; } \\
\text { immunomodulatory effect }\end{array}$ & $\begin{array}{l}\text { Prophylactic and } \\
\text { therapeutic effect } \\
\text { against diarrhoea }\end{array}$ & [41] \\
\hline $\begin{array}{l}\text { Holstein-Friesian dairy cows } \\
\text { with clinical or subclinical } \\
\text { mastitis }\end{array}$ & $\begin{array}{l}\text { S. aureus strains } \\
\text { obtained from cows } \\
\text { with subclinical and } \\
\text { clinical mastitis, pig } \\
\text { farm and human } \\
\text { infections }\end{array}$ & $\begin{array}{c}0.1 \mathrm{~mL} \text { phage cocktail } \\
\text { (STA1.ST29, EB1.ST11, and } \\
27) 1.2 \times 10^{8} \mathrm{PFU} / \mathrm{mL} \text { or } 1.2 \\
\times 10^{9} \mathrm{PFU} / \mathrm{mL} \\
\text { against } S . \text { aureus inoculated } \\
\text { into about } 5.0 \mathrm{~mL} \text { of milk } \\
\text { obtained from cows with } \\
\text { mastitis }\end{array}$ & $\begin{array}{l}\text { Significant reduction of } S \text {. } \\
\text { aureus in milk-2 } \log _{10} \\
\text { CFU / mL in vitro }\end{array}$ & Antibacterial activity & [117] \\
\hline $\begin{array}{l}3 \text { female Yorkshire pigs } \\
\text { weighing } 60 \mathrm{~kg}\end{array}$ & S. aureus ulcers & $\begin{array}{l}\text { S. aureus F } 44 / 10 \text { and } \\
\text { F125/10, inoculated } \\
\text { topically at } 10^{8} \text { to } 10^{9} \mathrm{PFU}\end{array}$ & $\begin{array}{c}\text { Slight reduction of } S \text {. aureus } \\
\text { strains, reduction of ulcerous } \\
\text { changes }\end{array}$ & $\begin{array}{l}\text { Therapeutic effect on } \\
\text { skin ulcers }\end{array}$ & [118] \\
\hline $\begin{array}{c}16 \text { small pigs } 3 \text { to } 4 \text { weeks } \\
\text { old }\end{array}$ & $\begin{array}{l}\text { Salmonella enterica ser. } \\
\text { Typhimurium } \\
\text { at } 5 \times 10^{8} \mathrm{CFU} \mathrm{mL}\end{array}$ & $\begin{array}{c}\text { Microencapsulated alginate } \\
\text { beads containing 16-phage } \\
\text { cocktail }(S E P-1, S G P-1, \\
\text { STP-1, SS } 3 P P-1, S T P-2, \\
\text { SChP-1, SAP-1, SAP-2), } \sim 10^{9} \\
\text { to } 10^{10} \mathrm{PFU} / \mathrm{mL} \text { by gavage }\end{array}$ & $\begin{array}{c}\text { Significant early reduction } \\
(99 \%) \text { in concentration of } S \text {. } \\
\text { Typhimurium } 2 \text { to } 3 \log _{10} \\
\text { CFU/g in the ileum, caecum } \\
\text { and tonsils; } \\
\text { significant influence on } \\
\text { health status and AWG of } \\
\text { pigs }\end{array}$ & $\begin{array}{l}\text { Prophylactic and } \\
\text { therapeutic effect }\end{array}$ & [119] \\
\hline 3-week-old weaned pigs & $\begin{array}{l}\text { E. coli }(\text { ETEC); } \\
\text { O149:H10:F4 }\end{array}$ & $\begin{array}{c}\text { Oral administration of phage } \\
\text { cocktail GJ1-GJ7 or } \\
\text { mono-phage: prophylactic } \\
10^{10} \text { PFU/pig or therapeutic } \\
10^{8} \mathrm{PFU} / \text { pig }\end{array}$ & $\begin{array}{l}\text { Significant reduction of } \\
\text { diarrhoea; reduction of } \\
\text { duration of diarrhoea }<2 \\
\text { days, mean diarrhoea score, } \\
\text { and mean composite } \\
\text { diarrhoea score significant } \\
\text { reduction of ETEC strains; } \\
\text { protection against diarrhoea }\end{array}$ & $\begin{array}{l}\text { Prophylactic and } \\
\text { therapeutic effect } \\
\text { against diarrhoea }\end{array}$ & [120] \\
\hline Weaned pigs $>4$ weeks old & $\begin{array}{c}\text { Oral challenge with } \\
5 \text { mL of } \\
\text { 109 CFU/mL Salmonella } \\
\text { Typhimurium }\end{array}$ & $\begin{array}{l}\text { Microencapsulated phage } \\
\text { cocktail in feed }\left(5 \times 10^{11}\right. \\
\text { PFU) for } 5 \text { days before } \\
\text { challenge with Salmonella } \\
\text { Typhimurium }\end{array}$ & $\begin{array}{c}\text { Reduction of } S \text {. } \\
\text { Typhimurium in ileum and } \\
\text { caecum by about } 1 \log _{10} \\
\text { CFU/g }\end{array}$ & $\begin{array}{l}\text { Therapeutic and } \\
\text { prophylactic effect }\end{array}$ & [121] \\
\hline 4-week-old weaned pigs & $\begin{array}{c}\text { Salmonella enterica } \\
\text { serovar Typhimurium }\end{array}$ & $\begin{array}{c}5 \mathrm{~mL} \text { of a } 8-\text { phage cocktail at } \\
10^{9} \mathrm{PFU} / \mathrm{mL} \text { (SEP-1, SGP-1, } \\
\text { STP-1, SS3eP-1, STP-2, } \\
\text { SChP-1, SAP-1, SAP-2) }\end{array}$ & $\begin{array}{l}\text { Significant reduction of } \\
\text { Salmonella Typhimurium; } \\
\text { 100\% lytic activity against } 34 \\
\text { Salmonella reference strains } \\
\text { and } 92.5 \% \text { lytic activity } \\
\text { against } 107 \text { wild strains }\end{array}$ & $\begin{array}{l}\text { Therapeutic effect in } \\
\text { diarrhoea }\end{array}$ & [122] \\
\hline
\end{tabular}


Table 4. Cont.

\begin{tabular}{|c|c|c|c|c|c|}
\hline Animal Species & Pathogen Species & Phage Treatment & Results & Treatment Procedure & References \\
\hline $\begin{array}{l}\text { Merino cross wethers sheep } \\
\text { (1 year of age })\end{array}$ & $\begin{array}{l}\text { S. aureus strain ATCC } \\
25923\end{array}$ & $\begin{array}{l}\text { Phage cocktail CTSA } 2 \times 10^{8} \\
\text { PFU } / \mathrm{mL} \text { applied to right } \\
\text { and left sinuses }\end{array}$ & $\begin{array}{l}\text { Reduction of tissue damage; } \\
\text { reduction of } S \text {. aureus } \\
\text { colonization }\end{array}$ & $\begin{array}{l}\text { Therapeutic and } \\
\text { antibacterial activity }\end{array}$ & [123] \\
\hline $\begin{array}{l}20 \text { Canadian Arcott rams } \\
\text { weighing } 50 \mathrm{~kg}\end{array}$ & $\begin{array}{l}\text { E. coli } \mathrm{O} 157: \mathrm{H} 7\left(10^{9}\right. \\
\text { CFU } / \mathrm{mL}\end{array}$ & $\begin{array}{c}\text { Oral administration of } E \text {. coli } \\
\text { phage cocktail P5, P8 and } \\
\text { P11 (10 } 10 \text { PFU) administered } \\
\text { orally } 5 \text { times using a sterile } \\
60-\mathrm{mL} \text { syringe and stomach } \\
\text { tube }\end{array}$ & $\begin{array}{c}\text { Significant reduction } 2 \log _{10} \\
\text { CFU of intestinal E. coli } \\
\text { O157:H7 in sheep; total } \\
\text { elimination of bacteria in } \\
30 \% \text { of animals }\end{array}$ & $\begin{array}{l}\text { Prophylactic and } \\
\text { therapeutic effect }\end{array}$ & [124] \\
\hline $\begin{array}{l}\text { Ross broiler chickens at } 34 \mathrm{~d} \\
\text { of age }\end{array}$ & $\begin{array}{c}\text { S. enterica ser. } \\
\text { Enteritidis P125109; } S \text {. } \\
\text { enterica serotype } \\
\text { Typhimurium 4/74; } S \text {. } \\
\text { enterica serotype Hadar } \\
18\end{array}$ & $\begin{array}{l}\text { Bacteriophage suspensions } \\
\text { as antacid administered by } \\
\text { oral gavage } 9.0 \text { or } 11.0 \log _{10} \\
\text { PFU of } \varphi 151 \text { (S. enterica ser. } \\
\text { Enteritidis), } \varphi 25 \text { (S. enterica } \\
\text { ser. Hadar), or } \varphi 10(S . \\
\text { enterica ser. Typhimurium) }\end{array}$ & $\begin{array}{c}\text { Significant reduction of } S \text {. } \\
\text { enterica ser. Enteritidis and } \\
\text { Typhimurium caecal } \\
\text { colonization by } \geq 4.2 \log _{10} \\
\text { CFU within } 24 \mathrm{~h}\end{array}$ & $\begin{array}{l}\text { Therapeutic and } \\
\text { prophylactic effect }\end{array}$ & [125] \\
\hline Young chicks & $\begin{array}{c}\text { Salmonella } \\
\text { Typhimurium DT104 }\end{array}$ & $\begin{array}{l}\text { Single oral dose of phage } \\
\text { FO1 of } 10^{9} \text { (PFU)/chick in } \\
\text { encapsulated form }\end{array}$ & $\begin{array}{l}\text { Reduction of Salmonella } \\
\text { Typhimurium strains in } \\
\text { caecum }\end{array}$ & Antibacterial effect & [126] \\
\hline Vrolix chicks aged 20 days & Campylobacter jejuni & $\begin{array}{c}\text { 3-bacteriophage cocktail } \\
5 \times 10^{8} \text { PFU of CP14, CP81 } \\
\text { or CP68 }\end{array}$ & $\begin{array}{c}\text { Reduction of C. jejuni strains } \\
\text { in caeca by approx. } 3 \log _{10} \\
\text { CFU units }\end{array}$ & $\begin{array}{l}\text { Antibacterial and } \\
\text { protective effect }\end{array}$ & [127] \\
\hline Chickens & $\begin{array}{l}\text { Campylobacter jejuni; } \\
\text { S. enterica serovar } \\
\text { Enteritidis }\end{array}$ & $\begin{array}{c}\text { Direct inoculation onto } \\
\text { chicken skin, C. jejuni typing } \\
\text { phage } 12673 \text { at } 10^{6} \mathrm{PFU} / \mathrm{cm}^{2} \\
\text { of skin; } \\
\text { S. enterica serovar Enteritidis } \\
\text { phage P22, phage } 29 \mathrm{C}, 10^{3} \\
\mathrm{PFU} / \mathrm{cm}^{2} \text { of skin }\end{array}$ & $\begin{array}{l}\text { Significant reduction of } \\
\text { Campylobacter up to } 2 \log _{10} \\
\text { per unit area of skin within } \\
48 \text { h; reduction of } C \text {. jejuni } \sim 2 \\
\log _{10} \text { on experimentally } \\
\text { contaminated chicken skin } \\
\text { after phage application }\end{array}$ & $\begin{array}{l}\text { Therapeutic and } \\
\text { antibacterial effect }\end{array}$ & [128] \\
\hline $\begin{array}{l}\text { Ross strain } 308 \text { commercial } \\
\text { chicken broilers }\end{array}$ & Salmonella enterica & $\begin{array}{c}\text { 3-phage cocktail, } \\
\text { liposome/alginate, } \\
\text { encapsulated, } \\
10^{10} \text { PFU/animal for } 9 \text { days }\end{array}$ & $\begin{array}{l}\text { Significant decrease in } \\
\text { Salmonella spp. } \\
\text { concentration }(\sim 50 \%) \text { in } \\
\text { caeca }\end{array}$ & Antibacterial activity & [129] \\
\hline $\begin{array}{l}\text { Broiler chickens (Cobb 500) } \\
\text { at } 1 \mathrm{~d} \text { of age }\end{array}$ & E. coli ser 02 & $\begin{array}{l}\text { Sprayed with } 200 \mathrm{~mL} \text { of } \\
8 \times 10^{8} \mathrm{PFU} / \mathrm{mL} \text { phage } \\
\text { SPR02 }\end{array}$ & $\begin{array}{l}\text { Significant reduction of } \\
\text { mortality by }>10 \%\end{array}$ & $\begin{array}{l}\text { Antibacterial and } \\
\text { protective effect }\end{array}$ & [130] \\
\hline 8-day-old quail & $\begin{array}{l}\text { Oral challenge with } 100 \\
\mu \mathrm{L} \text { of } 1.2 \times 10^{9} \mathrm{CFU} \\
\mathrm{ml}^{-1} \mathrm{~S} . \text { Enteritidis }\end{array}$ & $\begin{array}{l}\text { Oral application of } 100 \mu \mathrm{L} \text { of } \\
10^{6} \mathrm{PFU} \mathrm{ml^{-1 }} \text { bacteriophage } \\
\text { for } 3 \text { days }\end{array}$ & $\begin{array}{l}\text { Reduction of } S \text {. Enteritidis in } \\
\text { caecal tonsils of Japanese } \\
\text { quails to } 33.3 \text { and } 20 \%, 24 \mathrm{~h} \\
\text { and } 7 \text { days after application; } \\
\text { prophylactic effect against } S \text {. } \\
\text { Enteritidis colonization, } \\
\text { increase in resistance against } \\
\text { Salmonella challenge }\end{array}$ & Prophylactic effect & [43] \\
\hline $\begin{array}{l}\text { 2-day-old New Zealand } \\
\text { White rabbits }\end{array}$ & $\begin{array}{l}\text { Oral infection with } \\
\text { Vibrio cholerae } 8 \times 10^{8} \\
\text { CFU }\end{array}$ & $\begin{array}{l}\text { Oral application of } 3 \text { phages } \\
\text { (Phi_2, } 24 \text { and X29) } 10^{9} \text { PFU }\end{array}$ & $\begin{array}{l}\text { Reduction of bacteria count } \\
\text { up to } 4 \log _{10} \mathrm{CFU} / \mathrm{g} ; \\
\text { full protection against } \\
\text { clinical signs of disease }\end{array}$ & $\begin{array}{l}\text { Prophylactic and } \\
\text { therapeutic effects }\end{array}$ & [131] \\
\hline $\begin{array}{c}120 \text { eight-week-old female } \\
\text { BALB } / \mathrm{c} \\
\text { mice }\end{array}$ & $\begin{array}{l}\text { Mycobacterium } \\
\text { ulcerans } \\
\text { as ulcerous infections }\end{array}$ & $\begin{array}{c}\text { Single dose of } \\
\text { mycobacteriophage D29 } \\
10^{8} \text { PFU / mouse } \\
\text { administered } 33 \text { days post } \\
\text { infection }\end{array}$ & $\begin{array}{c}\text { Progressive reduction of } \\
\text { footpad swelling by day } 150 \\
\text { post-infection } \\
\text { significant reduction of } M \text {. } \\
\text { ulcerans } 1.5-2 \log _{10} \text { CFU } / \mathrm{ml}\end{array}$ & $\begin{array}{l}\text { Therapeutic effect and } \\
\text { antipathogenic activity } \\
\text { effect }\end{array}$ & [132] \\
\hline Mice & Pseudomonas aeruginosa & $\begin{array}{c}\text { Bacteriophage PAK_P1 } \\
\text { intranasally at curative dose } \\
\text { of } 1.0 \times 10^{8} \mathrm{PFU} / \mathrm{mL} \text { or } \\
\text { prophylactic dose of } 1.0 \times \\
10^{9} \mathrm{PFU} \text { (MOI } 100 \text { ) }\end{array}$ & $\begin{array}{l}\text { Prophylaxis of acute } \\
\text { respiratory infections caused } \\
\text { by } P \text {. aeruginosa; significant } \\
\text { reduction of clinical signs; } \\
\text { resistance to infection; } \\
\text { stimulation of immune } \\
\text { response }\end{array}$ & $\begin{array}{l}\text { Therapeutic and } \\
\text { prophylactic effect }\end{array}$ & [75] \\
\hline $\begin{array}{l}\text { BALB-C female mice aged } 10 \\
\text { weeks }\end{array}$ & Pseudomonas aeruginosa & $\begin{array}{c}\text { Single dose of phage } \\
\text { MMI-Ps } 110^{7} \mathrm{PFU} \\
\text { suspension by intranasal } \\
\text { application }\end{array}$ & $\begin{array}{c}\text { Prophylaxis against } P \text {. } \\
\text { aeruginosa infection; } \\
\text { significant reduction of } \\
\text { bacterial content in lungs } \\
\text { about } 2 \log _{10}\end{array}$ & $\begin{array}{c}\text { Protective and } \\
\text { antibacterial effect }\end{array}$ & [133] \\
\hline $\begin{array}{c}\text { Female mice } \mathrm{C} 57 \mathrm{BL} / 6 \text { mice, } \\
\text { aged } 7 \text { to } 8 \text { weeks }\end{array}$ & Acinetobacter baumanni & $\begin{array}{l}\text { A. baumanni phage } \mathrm{B} \phi-\mathrm{C} 62 \\
\text { inoculated intranasally }(1 \times \\
\qquad 10^{10} \mathrm{PFU} / \mathrm{ml}\end{array}$ & $\begin{array}{l}100 \% \text { survival after } \\
\text { challenge with A. baumanni }\end{array}$ & $\begin{array}{l}\text { Therapeutic effect, } \\
\text { slight } \\
\text { immunostimulatory } \\
\text { effect }\end{array}$ & [134] \\
\hline
\end{tabular}


Table 4. Cont.

\begin{tabular}{|c|c|c|c|c|c|}
\hline Animal Species & Pathogen Species & Phage Treatment & Results & Treatment Procedure & References \\
\hline $\begin{array}{c}\mathrm{BALB} / \mathrm{c} \text { mice aged } 6-8 \\
\text { weeks }\end{array}$ & $\begin{array}{c}\text { Klebsiella } \\
\text { pneumonia-induced } \\
\text { pneumonia }\end{array}$ & $\begin{array}{c}\text { Bacteriophage suspension } 2 \\
\times 10^{9} \mathrm{PFU} / \text { mouse applied } \\
\text { in a single dose i.n. }\end{array}$ & $\begin{array}{l}\text { Significant decrease in } \\
\text { duration of illness and } \\
\text { microscopic lesions; } \\
\text { suppression of necrosis, } \\
\text { bronchiolitis, and infiltration } \\
\text { of inflammatory cells }\end{array}$ & Therapeutic effect & [82] \\
\hline BALB/c mice & $\begin{array}{c}\text { Klebsiella pneumoniae } \\
\text { B5055 }\end{array}$ & $\begin{array}{c}50 \mu \mathrm{L} \text { of } 10^{8} \mathrm{PFU} / \mathrm{mL} \text { single } \\
\text { and 5-phage cocktail applied } \\
\text { topically at wound site } \\
\text { (Kpn1, Kpn2, Kpn3, Kpn4 } \\
\text { and Kpn5) }\end{array}$ & $\begin{array}{c}\text { Significant reduction of } K . \\
\text { pneumoniae load to } 4.32,4.64, \\
4.42,4.11 \text { and } 4.27 \mathrm{log} \\
\mathrm{CFU} / \mathrm{mL} \text {; rapid healing of } \\
\text { wounds in all phage-treated } \\
\text { groups }\end{array}$ & $\begin{array}{l}\text { Therapeutic and } \\
\text { antibacterial activity }\end{array}$ & [135] \\
\hline $\begin{array}{l}\text { Male Wistar rats; 9-10 weeks } \\
\text { old }\end{array}$ & $\begin{array}{l}\text { Staphylococcus } \\
\text { aureus-associated } \\
\text { pneumonia }\end{array}$ & $\begin{array}{c}\text { Intravenous application of } \\
\text { cocktail of } 4 \text { phages } \\
\left(2-3 \times 10^{9} \mathrm{PFU} / \mathrm{mL} \text { of } 2003\right. \\
2002,3 \mathrm{~A}, \text { and K }\end{array}$ & $\begin{array}{l}\text { Increase in survival from } 0 \% \\
\text { to } 58 \% \text { significant reduction } \\
\text { of bacterial content in the } \\
\text { lung }\left(1.2 \times 10^{6} \mathrm{CFU} / \mathrm{g} \text { of }\right. \\
\text { tissue for survivors vs. } \\
1.2 \times 10^{9} \mathrm{CFU} / \mathrm{g} \text { for } \\
\text { nonsurviving animals); } \\
\text { reduction of lung damage }\end{array}$ & $\begin{array}{l}\text { Therapeutic and } \\
\text { immunomodulatory } \\
\text { effect; antibacterial } \\
\text { activity }\end{array}$ & [136] \\
\hline $\begin{array}{l}\text { New Zealand White infant } \\
\text { rabbits (aged } 3 \text { days) and } \\
\text { CD-1 infant mice (aged } 4 \\
\text { and } 5 \text { days) }\end{array}$ & $\begin{array}{c}\text { Vibrio cholerae; oral } \\
\text { administration of } \\
5 \times 10^{8} \mathrm{CFU} / \text { rabbit or } \\
\text { mouse }\end{array}$ & $\begin{array}{c}\text { Oral administration of phage } \\
\text { cocktail }\left(3 \times 10^{7} \text { or } 10^{8}\right. \\
\text { PFU/rabbit or mouse })\end{array}$ & $\begin{array}{l}\text { Protective effect against } \\
\text { cholera via significant } \\
\text { reduction of caecal } \\
\text { colonization by } V \text {. cholerae; } \\
\text { protection against } \\
\text { cholera-like diarrhoea }\end{array}$ & $\begin{array}{l}\text { Prophylactic and } \\
\text { therapeutic effect }\end{array}$ & [137] \\
\hline $\begin{array}{l}\text { New Zealand White rabbits } \\
\text { 2-day-old }\end{array}$ & $\begin{array}{l}\text { Vibrio cholera } 5 \times 10^{8} \\
\text { CFU per animal }\end{array}$ & $\begin{array}{c}\text { Phage Phi_1 at } 1 \times 10^{9} \\
\text { PFU/animal orally } \\
\text { administered either } 6 \mathrm{~h} \\
\text { before or } 6 \mathrm{~h} \text { after bacterial } \\
\text { challenge }\end{array}$ & $\begin{array}{c}\text { Protection against clinical } \\
\text { signs of cholera; lack of } \\
\text { diarrhoea; } \\
\text { significant reduction of } 2-4 \\
\log _{10} \text { CFU/g V. cholera }\end{array}$ & $\begin{array}{l}\text { Prophylactic and } \\
\text { therapeutic effect }\end{array}$ & [131] \\
\hline $\begin{array}{l}\text { Female C57BL6/SJL mice as } \\
\text { cow mastitis infection model }\end{array}$ & $\begin{array}{c}\text { Streptococcus dysgalactiae } \\
\text { NRRL B-65273, S. } \\
\text { agalactiae NRRL B-65272, } \\
\text { and S. uberis NRRL } \\
\text { B-65274 }\end{array}$ & $\begin{array}{c}\text { Direct application into } \\
\text { mammary gland: } \\
\text { Streptococcus spp. phage } \\
\text { endolysins } 25 \mu \mathrm{g} / \text { gland for } \\
\lambda \mathrm{SA} 2,250 \mu \mathrm{g} / \text { gland for B30, } \\
\text { and } 12.5(\lambda \mathrm{SA} 2)+125 \text { (B30) } \\
\mu \mathrm{g} / \text { gland }\end{array}$ & $\begin{array}{l}\text { Significant reduction of } S \text {. } \\
\text { dysgalactiae content by } 3.5 \\
\log _{10} \text { CFU; S. agalactiae ( } 2 \\
\text { log); S. uberis ( } 4 \text { log); } \\
\text { protection against clinical } \\
\text { signs of mastitis }\end{array}$ & $\begin{array}{l}\text { Therapeutic effect and } \\
\text { antibacterial activity }\end{array}$ & [138] \\
\hline
\end{tabular}

\section{Conclusions}

To sum up, bacteriophages have many properties indicating their potential suitability as therapeutic or/and prophylactic agents. Future research on the scope of phages will provide a good picture of their potential to treat infections caused by multidrug-resistant bacteria. However, as bacteriophages are essentially 'living' drugs, the study of their use for therapy or biocontrol spans from purely clinical observations to molecular analysis to considerations of immunology and ecology. Due to the antibiotic resistance crisis, there is a compelling need for alternative safe and selectively effective antibacterial agents.

Author Contributions: Writing the original draft, literature review and collection, M.M.M.A.; literature review and resources, visualization, M.D.; conception of the manuscript, writing and editing of the manuscript, R.U.-C. All authors have read and agreed to the published version of the manuscript.

Funding: This research received no external funding.

Conflicts of Interest: The authors declare no conflict of interest.

\section{Abbreviations}

AMPs antimicrobial peptides

ATCC American Type Culture Collection

BALB Bagg Albino Mouse

BAVS Bacterial and Archaeal Viruses Subcommittee

CD cluster of differentiation

$\mathrm{CFU}$ colony-forming unit 


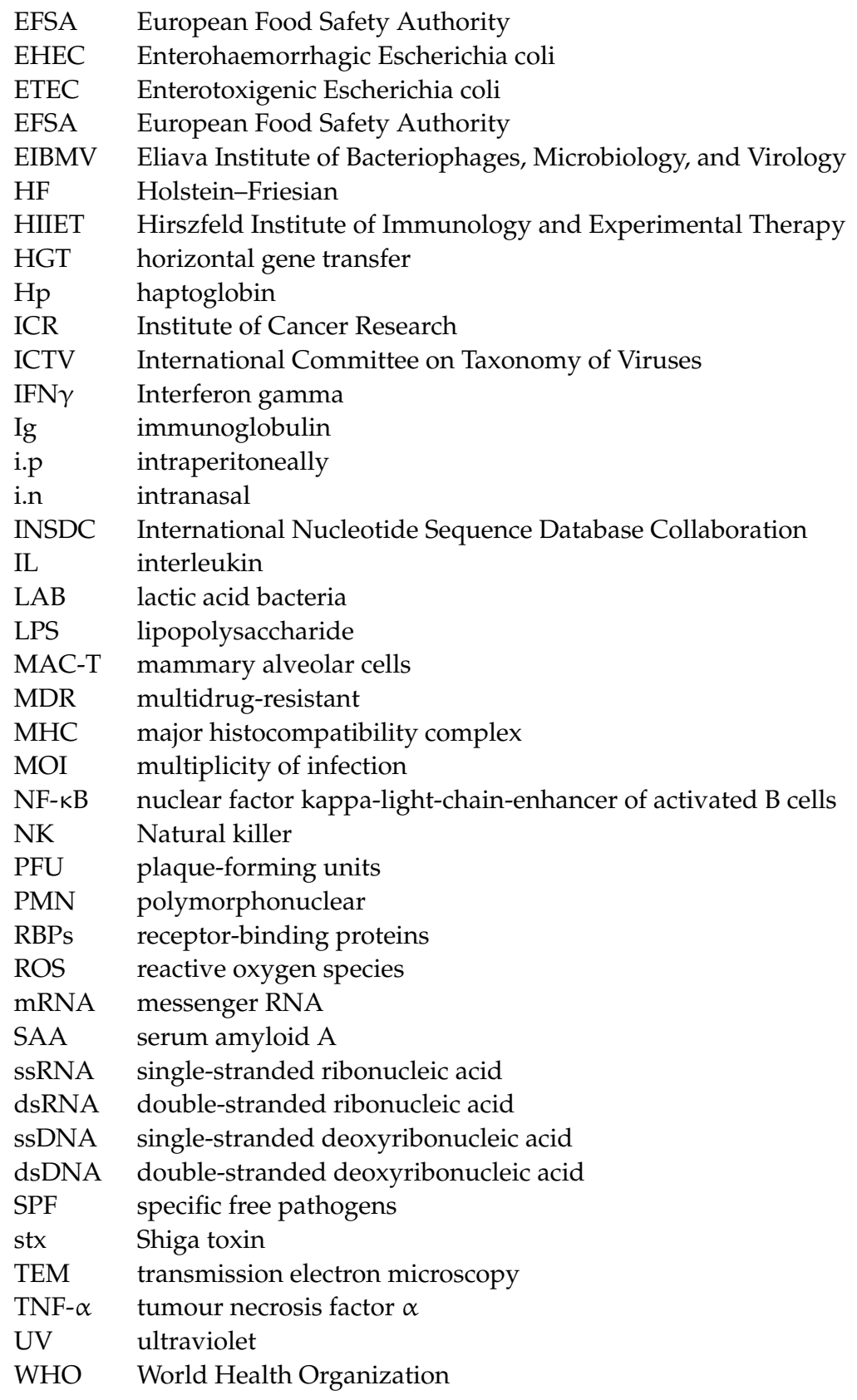

\section{References}

1. Ssekatawa, K.; Byarugabaa, D.K.; Katoa, C.D.; Wampandea, E.M.; Ejobia, F.; Tweyongyerea, R.; Nakavumaa, J.L. A review of phage mediated antibacterial applications. Alexandria J. Med. 2021, 57,1-20. [CrossRef]

2. World Health Organization. World Health Organization Estimates of the Global Burden of Foodborne Diseases; WHO: Geneva, Switzerland, 2015; Available online: http:/ / apps.who.int (accessed on 22 November 2021).

3. Alali, W.Q.; Thakur, S.; Berghaus, R.D.; Martin, M.P.; Gebreyes, W.A. Prevalence anddistribution of Salmonella in organic andconventional broiler poultry farms. Foodborne Pathog. Dis. 2010, 7, 1363-1371. [CrossRef]

4. Sillankorva, S.M.; Oliveira, H.; Azeredo, J. Bacteriophages and their role in food safety. Inter. J. Microbiol 2012, $2012,863945$. [CrossRef] [PubMed]

5. Niu, Y.D.; Cook, S.R.; Wang, J.; Klima, C.L.; Hsu, Y.; Kropinski, A.M.; Turner, D.; McAllister, T.A. Comparative analysis of multiple inducible phages from Mannheimia haemolytica. BMC Microbiol. 2015, 15, 175. [CrossRef]

6. European Food Safety Authority (EFSA). The European Union summary report on antimicrobial resistance in zoonotic and indicator bacteria from humans, animals and food in 2017. EFSA J. 2018, 17, e05598.

7. Eichenberger, E.M.; Thaden, J.T. Epidemiology and mechanisms of resistance of extensively drug resistant Gram-negative bacteria. Antibiotics 2019, 8, 37. [CrossRef] 
8. Donkor, E.S.; Newman, M.J.; Yeboah-Manu, D. Epidemiological aspects of non-human antibiotic usage and resistance: Implications for the control of antibiotic resistance in Ghana. Trop. Med. Int. Health 2012, 17, 462-468. [CrossRef]

9. Żbikowska, K.; Michalczuk, M.; Dolka, B. The use of bacteriophages in the poultry industry. Animals 2020, 10, 872. [CrossRef]

10. Regulation (EU) 2019/6 Of The European Parliament And Of The Council of 11 December 2018 on veterinary medicinal products and repealing Directive 2001/82/EC. Offical J. EU.Union. 2019, pp. 43-167. Available online: https:/ / eur-lex.europa.eu/eli/reg/ 2019/6/oj (accessed on 22 November 2021).

11. Orlova, E. Bacteriophages and Their Structural Organisation, 1st ed.; IntechOpen: London, UK, 2012; pp. 3-30.

12. Lenski, R.E. Dynamics of interactions between bacteria and virulent bacteriophage. In Advances in Microbial Ecology; Springer: Chicago, IL, USA, 1988; pp. 1-44.

13. Batinovic, S.; Wassef, F.; Knowler, S.A.; Rice, D.T.F.; Stanton, C.R.; Rose, J.; Tucci, J.; Nittami, T.; Vinh, A.; Drummond, G.R.; et al. Bacteriophages in natural and artificial environments. Pathogens 2019, 8, 100. [CrossRef] [PubMed]

14. Brüssow, H. Bacteria between protists and phages: From antipredation strategies to the evolution of pathogenicity. Mol. Microbiol. 2007, 65, 583-589. [CrossRef]

15. Vikram, A.; Tokman, J.I.; Woolston, J.; Sulakvelidze, A. Phage Biocontrol Improves Food Safety by Significantly Reducing the Level and Prevalence of Escherichia coli O157:H7 in Various Foods. J. Food Prot. 2021, 83, 668-676. [CrossRef] [PubMed]

16. Viazis, S.; Akhtar, M.; Feirtag, J.; Brabban, A.D.; Diez-Gonzalez, F. Isolation and characterization of lytic bacteriophages against enterohaemorrhagic Escherichia coli. J. Appl. Microbiol. 2011, 110, 1323-1331. [CrossRef]

17. Dec, M.; Wernicki, A.; Urban-Chmiel, R. Efficacy of experimental phage therapies in livestock. Anim. Health Res. Rev. 2020, 21, 69-83. [CrossRef] [PubMed]

18. De Jonge, P.A.; Nobrega, F.L.; Brouns, S.J.; Dutilh, B.E. Molecular and evolutionary determinants of bacteriophage host range. Trends Microb. 2019, 27, 51-63. [CrossRef]

19. Dunne, M.; Rupf, B.; Tala, M.; Qabrati, X.; Ernst, P.; Shen, Y.; Sumrall, E.; Heeb, L.; Plückthun, P.; Loessner, M.J.; et al. Reprogramming Bacteriophage Host Range through Structure-Guided Design of Chimeric Receptor Binding Proteins. Cell Reports 2019, 29, 1336-1350. [CrossRef]

20. Twort, F.W. An investigation on the nature of ultramicroscopic viruses. Lancet 1915, 186, 1241-1243. [CrossRef]

21. d'Herelle, F. Sur un microbe invisible antagoniste des bacilles dysentériques. Comptes Rendus de l'Académie Sci. Paris 1917, 165, 173-175.

22. d'Herelle, F. Sur le role du microbe bacteriophage dans la typhose aviare. C. R. Acad. Sci. 1919, 169, 932-934.

23. Duckworth, D.H. Who discovered bacteriophage? Bacteriol. Rev. 1976, 40, 793. [CrossRef]

24. Abedon, S.T.; Thomas-Abedon, C.; Thomas, A.; Mazure, H. Bacteriophage prehistory: Is or is not Hankin, 1896, a phage reference. Bacteriophage 2011, 1, 174-178. [CrossRef]

25. Opal, S.M. The evolution of the understanding of sepsis, infection, and the host response: A brief history. Crit. Care Clin. 2009, 25, 637-663. [CrossRef] [PubMed]

26. Rello, J.; Bunsow, E.; Perez, A. What if there were no new antibiotics? A look at alternatives. Expert Rev. Clin. Pharmacol. 2016, 9 , 1547-1555. [CrossRef] [PubMed]

27. Sulakvelidze, A.; Alavidze, Z.; Morris, J.G. Bacteriophage therapy. Antimicrob Agents Chemother. 2001, 45, 649-659. [CrossRef] [PubMed]

28. Kutter, E.; De Vos, D.; Gvasalia, G.; Alavidze, Z.; Gogokhia, L.; Kuhl, S.; Abedon, S.T. Phage therapy in clinical practice: Treatment of human infections. Curr. Pharm. Biotechnol. 2010, 11, 69-86. [CrossRef]

29. Górski, A.; Miedzybrodzki, R.; Weber-Dąbrowska, B.; Fortuna, W.; Letkiewicz, S.; Rogóż, P.; Jończyk-Matysiak, E.; Dabrowska, K.; Majewska, J.; Borysowski, J. Phage Therapy: Combating Infections with Potential for Evolving from Merely a Treatment for Complications to Targeting Diseases. Front. Microbiol. 2016, 7, 1515. [CrossRef]

30. International Nucleotide Sequence Database Collaboration. Available online: https:/ / www.insdc.org/ (accessed on 28 October 2021).

31. Wittebole, X.; De Roock, S.; Opal, S.M. A historical overview of bacteriophage therapy as an alternative to antibiotics for the treatment of bacterial pathogens. Virulence 2014, 5, 226-235. [CrossRef]

32. Adriaenssens, E.M.; Krupovic, M.; Knezevic, P.; Ackermann, H.W.; Barylski, J.; Brister Clokie, R.M.C.; Duffy, S.; Dutilh, B.E.; Edwards, R.A.; Enault, F.; et al. Taxonomy of prokaryotic viruses: 2016 update from the ICTV bacterial and archaeal viruses subcommittee. Archiv. Virol. 2017, 162, 1153-1157. [CrossRef]

33. Pyzik, E.; Radzki, R.P.; Urban-Chmiel, R. Experimental Phage Therapies in Companion Animals with A Historical Rewiev. Curr. Clin. Pharmacol. 2021, 16, 17-29.

34. García, P.; Rodríguez, L.; Rodríguez, A.; Martínez, B. Food biopreservation: Promising strategies using bacteriocins, bacteriophages and endolysins. Trends Food Sci. Technol. 2010, 21, 373-382. [CrossRef]

35. Rakhuba, D.V.; Kolomiets, E.I.; Dey, E.S.; Novik, G.I. Bacteriophage receptors, mechanisms of phage adsorption and penetration into host cell. Pol. J. Microbiol. 2010, 59, 145-155. [CrossRef]

36. Hanlon, G.W. Bacteriophages: An appraisal of their role in the treatment of bacterial infections. Int. J. Antimicrob. Agen. 2007, 30, 118-128. [CrossRef]

37. Wernicki, A.; Nowaczek, A.; Urban-Chmiel, R. Bacteriophage therapy to combat bacterial infections in poultry. Virol. J. 2017, 14, 179. [CrossRef] [PubMed] 
38. Clark, D.P.; Pazdernik, N.J. Chapter 7. Cloning Genes for Analysis. In Molecular Biology, 2nd ed.; Academic Cell Update Edition; Elsevier Inc.: Waltham, MA, USA, 2013; pp. 194-226.

39. Hyman, P.; Abedon, S.T. Bacteriophage Host Range and Bacterial Resistance, in Advances in Applied Microbiology; Elsevier: Amsterdam, The Netherlands, 2010; pp. 217-248.

40. Clokie, M.R.; Millard, A.D.; Letarov, A.V.; Heaphy, S. Phages in nature. Bacteriophage 2011, 1, 31-45. [CrossRef] [PubMed]

41. Alomari, M.M.M.; Dec, M.; Nowaczek, A.; Puchalski, A.; Wernicki, A.; Kowalski, C.J.; Urban-Chmiel, R. Therapeutic and Prophylactic Effect of the Experimental Bacteriophage Treatment to Control Diarrhea Caused by E. coli in Newborn Calves. ACS Infect. Dis. 2021, 7, 2093-2101. [CrossRef] [PubMed]

42. Wagenaar, J.A.; Van Bergen, M.A.; Mueller, M.A.; Wassenaar, T.M.; Carlton, R.M. Phage therapy reduces Campylobacter jejuni colonization in broilers. Vet. Microbiol. 2005, 109, 275-283. [CrossRef]

43. Ahmadi, M.; Karimi Torshizi, M.A.; Rahimi, S.; Dennehy, J.J. Prophylactic bacteriophage administration more effective than post-infection Administration in Reducing Salmonella enterica serovar Enteritidis shedding in quail. Front. Microbiol. 2016, 7, 1253. [CrossRef]

44. Kazi, M.; Annapure, U.S. Bacteriophage biocontrol of foodborne pathogens. J. Food Sci. Tech. 2016, 53, 1355-1362. [CrossRef]

45. Silva, J.; Sauvageau, D. Bacteriophages as antimicrobial agents against bacterial contaminants in yeast fermentation processes. $J$. Biotech. Biof. 2014, 7, 123. [CrossRef]

46. Roy, B.; Ackermann, H.W.; Pandian, S.; Picard, G.; Goulet, J. Biological inactivation of adhering Listeria monocytogenes by listeriaphages and a quaternary ammonium compound. Appl. Environ. Microbiol. 1993, 59, 2914-2917. [CrossRef]

47. Ho, Y.H.; Tseng, C.C.; Wang, L.S.; Chen, Y.T.; Ho, G.J.; Lin, T.Y.; Wang, L.Y.; Chen, L.K. Application of bacteriophage-containing aerosol against nosocomial transmission of carbapenem-resistant acinetobacter baumannii in an intensive care unit. PLoS ONE 2016, 11, e0168380.

48. Le, T.S.; Southgate, P.C.; O'Connor, W.; Poole, S.; Kurtböke, D.I. Bacteriophages as biological control agents of enteric bacteria contaminating edible oysters. Curr. Microbiol. 2018, 75, 611-619. [CrossRef]

49. Sieiro, C.; Areal-Hermida, L.; Pichardo-Gallardo, Á.; Almuiña-González, R.; de Miguel, T.; Sánchez, S.; Sánchez-Pérez, Á.; Villa, T.G. A Hundred Years of Bacteriophages: Can Phages Replace Antibiotics in Agriculture and Aquaculture? Antibiotics 2020, 9 , 493. [CrossRef] [PubMed]

50. Bai, J.; Kim, Y.T.; Ryu, S.; Lee, J.H. Biocontrol and rapid detection of food-borne pathogens using bacteriophages and endolysins. Front. Microbiol. 2016, 7, 1-15. [CrossRef]

51. Sultan, I.; Rahman, S.; Jan, A.T.; Siddiqui, M.T.; Mondal, A.H.; Haq, Q.M.R. Antibiotics, resistome and resistance mechanisms: A bacterial perspective. Front. Microbiol. 2018, 9, 2066. [CrossRef]

52. Park, K.; Cha, K.E.; Myung, H. Observation of inflammatory responses in mice orally fed with bacteriophage T 7. J. Appl. Microb. 2014, 117, 627-633. [CrossRef]

53. Van Belleghem, J.D.; Clement, F.; Merabishvili, M.; Lavigne, R.; Vaneechoutte, M. Pro-and anti-inflammatory responses of peripheral blood mononuclear cells induced by Staphylococcus aureus and Pseudomonas aeruginosa phages. Sci. Rep. 2017, 7, $1-13$.

54. Zhang, L.; Hou, X.; Sun, L.; He, T.; Wei, R.; Pang, M.; Wang, R. Staphylococcus aureus bacteriophage suppresses LPS-induced inflammation in MAC-T bovine mammary epithelial cells. Front. Microbiol. 2018, 9, 1614. [CrossRef]

55. Smith, H.W.; Huggins, M.B.; Shaw, K.M. Factors influencing the survival and multiplication of bacteriophages in calves and in their environment. J. Gen. Microbiol. 1987, 133, 1127-1135. [CrossRef]

56. Cooper, R.A.; Bjarnsholt, T.; Alhede, M. Biofilms in wounds: A review of present knowledge. J. Wound. Care 2014, 23, 570-580. [CrossRef] [PubMed]

57. Reardon, S. Phage therapy gets revitalized: The rise of antibiotic resistance rekindles interest in a century-old virus treatment. Nature 2014, 510, 15-17. [CrossRef]

58. Kutter, E.M.; Kuhl, S.J.; Abedon, S.T. Re-establishing a place for phage therapy in western medicine. Future Microbiol. 2015, 10, 685-688. [CrossRef]

59. Alomari, M.M.M.; Nowaczek, A.; Dec, M.; Urban-Chmiel, R. Antibacterial activity of bacteriophages isolated from poultry against Shiga-toxic strains of Esherichia coli isolated from calves. Med. Weter. 2016, 72, 699-703. [CrossRef]

60. Cisek, A.A.; Dąbrowska, I.; Gregorczyk, K.P.; Wyżewski, Z. Phage therapy in bacterial infections treatment: One hundred years after the discovery of bacteriophages. Curr. Microbiol. 2017, 74, 1-7. [CrossRef]

61. Podlacha, M.; Grabowski, Ł.; Kosznik-Kawśnicka, K.; Zdrojewska, K.; Stasiłojć, M.; Węgrzyn, G.; Alicja Węgrzyn, A. Interactions of Bacteriophages with Animal and Human Organisms-Safety Issues in the Light of Phage Therapy. Int. J. Mol. Sci. 2021, 22, 8937. [CrossRef]

62. Ann, T.W.; Kim, S.J.; Lee, Y.D.; Park, J.H.; Chang, H.I. The Immune-Enhancing Effect of the Cronobacter Sakazakii ES2 Phage Results in the Activation of Nuclear Factor-KB and Dendritic Cell Maturation via the Activation of IL-12p40 in the Mouse Bone Marrow. Immunol. Lett. 2014, 157, 1-8. [CrossRef]

63. Van Belleghem, J.D.; Dabrowska, K.; Vaneechoutte, M.; Barr, J.J.; Bollyky, P.L. Interactions between Bacteriophage, Bacteria, and the Mammalian Immune System. Viruses 2019, 11, 10. [CrossRef] [PubMed]

64. Geier, M.R.; Trigg, M.E.; Merril, C.R. Fate of bacteriophage lambda in non-immune germ-free mice. Nature 1973, 246, $221-223$. [CrossRef] [PubMed] 
65. Tiwari, B.R.; Kim, S.; Rahman, M.; Kim, J. Antibacterial efficacy of lytic Pseudomonas bacteriophage in normal and neutropenic mice models. J. Microbiol. 2011, 49, 994-999. [CrossRef]

66. Tóthová, L.; Celec, P.; Bábí`cková, J.; Gajdošová, J.; Al-Alami, H.; Kamodyova, N.; Drahovská, H.; Liptáková, A.; Tur `na, J.; Hodosy, J. Phage Therapy of Cronobacter-Induced Urinary Tract Infection in Mice. Med. Sci. Monit. 2011, 17, 173-178. [CrossRef]

67. Reyes, A.; Semenkovich, N.P.; Whiteson, K.; Rohwer, F.; Gordon, J.I. Going viral: Next generation sequencing applied to human gut phage populations. Nat. Rev. Microbiol. 2012, 10, 607-610. [CrossRef] [PubMed]

68. Dabrowska, K.; Switała-Jelen, K.; Opolski, A.; Weber-Dabrowska, B.; Gorski, A. Bacteriophage penetration in vertebrates. J. Appl. Microbiol. 2005, 98, 7-13. [CrossRef] [PubMed]

69. Sarker, S.A.; McCallin, S.; Barretto, C.; Berger, B.; Pittet, A.C.; Sultana, S.; Krause, L.; Huq, S.; Bibiloni, R.; Bruttin, A.; et al. Oral T4-like phage cocktail application to healthy adult volunteers from Bangladesh. Virology 2012, 434, 222-232. [CrossRef]

70. Wright, A.; Hawkins, C.H.; Änggård, E.E.; Harper, D.R. A controlled clinical trial of a therapeutic bacteriophage preparation in chronic otitis due to antibiotic-resistant Pseudomonas aeruginosa; a preliminary report of efficacy. Clin. Otolaryngol. 2009, 34, 349-357. [CrossRef]

71. Górski, A.; Miedzybrodzki, R.; Borysowski, J.; Dabrowska, K.; Wierzbicki, P.; Ohams, M.; Korczak-Kowalska, G.; OlszowskaZaremba, N.; Łusiak-Szelachowska, M.; KŁak, M.; et al. Phage as a Modulator of Immune Responses: Practical Implications for Phage Therapy. Adv. Virus Res. 2012, 83, 41-71. [PubMed]

72. Przerwa, A.; Zimecki, M.; Switała-Jelen, K.; Dabrowska, K.; Krawczyk, E.; Łuczak, M.; Weber-Dabrowska, B.; Syper, D.; Miedzybrodzki, R.; Górski, A. Effects of bacteriophages on free radical production and phagocytic functions. Med. Microbiol. Immunol. 2006, 195, 143-150. [CrossRef]

73. Ly-Chatain, M.H. The factors affecting effectiveness of treatment in phages therapy. Front. Microbiol. 2014, 18, 51. [CrossRef] [PubMed]

74. Sulakvelidze, A.; Kutter, E. Bacteriophage Therapy in Humans. Bacteriophages: Biology and Applications; CRC Press: Boca Raton, FL, USA, 2004; pp. 381-436.

75. Roach, D.R.; Leung, C.Y.; Henry, M.; Morello, E.; Singh, D.; Di Santo, J.P. Synergy between the host immune system and bacteriophage is essential for successful phage therapy against an acute respiratory pathogen. Cell Host Microb. 2017, 22, 38.e-47.e. [CrossRef]

76. Miernikiewicz, P.; Dąbrowska, K.; Piotrowicz, A.; Owczarek, B.; Wojas-Turek, J.; Kicielińska, J.; Rossowska, J.; Pajtasz-Piasecka, E.; Hodyra, K.; Macegoniuk, K.; et al. T4 phage and its head surface proteins do not stimulate inflammatory mediator production. PLoS ONE 2013, 8, e71036.

77. Pajtasz-Piasecka, E.; Rossowska, J.; Duś, D.; Weber-Dabrowska, B.; Zabłocka, A.; Górski, A. Bacteriophages support anti-tumor response initiated by DC-based vaccine against murine transplantable colon carcinoma. Immunol. Lett. 2008, 116, 24-32. [CrossRef]

78. Yıldızlı, G.; Coral, G.; Ayaz, F. Immunostimulatory Activities of Coliphages on In Vitro Activated Mammalian Macrophages. Inflammation 2020, 43, 595-604. [CrossRef]

79. Srivastava, A.S.; Kaido, T.; Carrier, E. Immunological factors that affect the in vivo fate of T7 phage in the mouse. J. Virol. Meth. 2004, 115, 99-104. [CrossRef]

80. Gogokhia, L.; Buhrke, K.; Bell, R.; Hoffman, B.; Brown, D.G.; Hanke-Gogokhia, C.; Ajami, N.J.; Wong, M.C.; Ghazaryan, A.; John, F.; et al. Expansion of Bacteriophages Is Linked to Aggravated Intestinal Inflammation and Colitis. Cell Host Microb. 2019, 25, 285-299. [CrossRef] [PubMed]

81. Majewska, J.; Kaźmierczak, Z.; Lahutta, K.; Lecion, D.; Szymczak, A.; Miernikiewicz, P.; Drapała, J.; Harhala, M.; Marek-Bukowiec, K.; Jędruchniewicz, N.; et al. Induction of Phage-Specific Antibodies by Two Therapeutic Staphylococcal Bacteriophages Administered per os. Front. Immunol. 2019, 10, 2607. [CrossRef]

82. Anand, T.; Virmani, N.; Kumar, S.; Mohanty, A.K.; Pavulraj, S.; Bera, B.C.; Vaid, R.K.; Ahlawat, U.; Tripathi, B.N. Phage therapy for treatment of virulent Klebsiella pneumoniae infection in a mouse model. J. Glob. Antimicrob. Resist. 2020, 21, 34-41. [CrossRef]

83. Biswas, B.; Adhya, S.; Washart, P.; Paul, B.; Trostel, A.N.; Powell, B.; Troste, A.N.; Powell, B.; Carlton, R.; Merril, C.R. Bacteriophage therapy rescues mice bacteremic from a clinical isolate of vancomycin-resistant Enterococcus faecium. Infect. Immun. 2002, 70, 204-210. [CrossRef] [PubMed]

84. Capparelli, R.; Nocerino, N.; Iannaccone, M.; Ercolini, D.; Parlato, M.; Chiara, M.; Iannelli, D. Bacteriophage therapy of Salmonella enterica: A fresh appraisal of bacteriophage therapy. J. Infect. Dis. 2010, 201, 52-61. [CrossRef]

85. Langbeheim, H.; Teitelbaum, D.; Arnon, R. Cellular immune response toward MS-2 phage and a synthetic fragment of its coat protein. Cell Immunol. 1978, 38, 193-197. [CrossRef]

86. Górski, A.; Ważna, E.; Dąbrowska, B.W.; Dąbrowska, K.; Świtała-Jeleń, K.; Międzybrodzki, R. Bacteriophage translocation. FEMS Immunol. Med. Microbiol. 2006, 46, 313-319. [CrossRef]

87. Moye, Z.D.; Woolston, J.; Sulakvelidze, A. Bacteriophage applications for food production and processing. Viruses 2018, 10, 205. [CrossRef] [PubMed]

88. Abedon, S.T. Ecology of anti-biofilm agents II. Bacteriophage exploitation and biocontrol of biofilm bacteria. Pharmaceuticals 2015, 8, 559-589. [CrossRef]

89. Soffer, N.; Abuladze, T.; Woolston, J.; Li, M.; Hanna, L.F.; Heyse, S.; Charbonneau, D.; Sulakvelidze, A. Bacteriophages safely reduce Salmonella contamination in pet food and raw pet food ingredients. Bacteriophage 2016, 6, e1220347. [CrossRef] 
90. Food Safety. Available online: https://www.intralytix.com/index.php?page=food (accessed on 28 October 2021).

91. Połaska, M.; Sokołowska, B. Bacteriophages-a new hope or a huge problem in the food industry. AIMS Microbiol. 2019, 5, 324-346. [CrossRef] [PubMed]

92. Agricultural Biocontrol Applications. Available online: https://www.brimrosetechnology.com/biocontrol (accessed on 28 October 2021).

93. Sommer, J.; Trautner, C.; Witte, A.K.; Fister, S.; Schoder, D.; Rossmanith, P.; Mester, P.J. Don't shut the stable door after the phage has bolted-the importance of bacteriophage inactivation in food environments. Viruses 2019, 11, 468. [CrossRef] [PubMed]

94. PhageGuard. Available online: www.phageguard.com (accessed on 28 October 2021).

95. Vikram, A.; Woolston, J.; Sulakvelidze, A. Phage biocontrol applications in food production and processing. Curr. Iss. Mol. Biol. 2020, 40, 267-302.

96. U. S. Food \& Drug. Available online: https:/ / fda.report/media/111308/GRAS-Notice-000724 (accessed on 28 October 2021).

97. Mai, V.; Ukhanova, M.; Reinhard, M.K.; Li, M.; Sulakvelidze, A. Bacteriophage administration significantly reduces Shigella colonization and shedding by Shigella-challenged mice without deleterious side effects and distortions in the gut microbiota. Bacteriophage 2015, 5, e1088124. [CrossRef]

98. EFSA BIOHAZ Panel (EFSA Panel on Biological Hazards): Scientific opinion on the evaluation of the safety and efficacy of Listex TM P100 for reduction of pathogens on different ready-to-eat (RTE) food products. EFSA J. 2016, 14, 1-94.

99. Chhibber, S.; Kumari, S. Application of Therapeutic Phages in Medicine, Bacteriophages, Ipek Kurtboke, IntechOpen. 2012. Available online: https:/ / www.intechopen.com/chapters/32283 (accessed on 22 November 2021). [CrossRef]

100. Barrow, P.A.; Soothill, J.S. Bacteriophage therapy and prophylaxis: Rediscovery and renewed assessment of potential. Trends Microbiol. 1997, 5, 268-271. [CrossRef]

101. Matsuzaki, S.; Rashel, M.; Uchiyama, J.; Sakurai, S.; Ujihara, T.; Kuroda, M.; Ikeuchi, M.; Tani, T.; Fujieda, M.; Wakiguchi, H.; et al. Bacteriophage therapy: A revitalized therapy against bacterial infectious diseases. J. Infect. Chemother. 2005, 11, 211-219. [CrossRef]

102. Loc-Carrillo, C.; Abedon, S.T. Pros and cons of phage therapy. Bacteriophage 2011, 1, 111-114. [CrossRef]

103. Elbreki, M.; Ross, R.P.; Hill, C.; O’Mahony, J.; McAuliffe, O.; Coffey, A. Bacteriophages and their derivatives as biotherapeutic agents in disease prevention and treatment. J. Viruses 2014, 2014, 382539. [CrossRef]

104. Oliveira, J.; Castilho, F.; Cunha, A.; Pereira, M.J. Bacteriophage therapy as a bacterial control strategy in aquaculture. Aquaculture Inter. 2012, 20, 879-910. [CrossRef]

105. Iriarte, F.B.; Balogh, B.; Momol, M.T.; Smith, L.M.; Wilson, M.; Jones, J.B. Factors affecting survival of bacteriophage on tomato leaf surfaces. Appl. Environ. Microbiol. 2007, 73, 1704-1711. [CrossRef] [PubMed]

106. Pirnay, J.P.; Blasdel, B.G.; Bretaudeau, L.; Buckling, A.; Chanishvili, N.; Jason, R.; Corte-Real, S.; Debarbieux, L.; Dublanchet, A.; De VosJérôme, D.; et al. Quality and safety requirements for sustainable phage therapy products. Pharm. Res. 2015, 32, 2173-2179. [CrossRef]

107. Ryan, E.M.; Gorman, S.P.; Donnelly, R.F.; Gilmore, B.F. Recent advances in bacteriophage therapy: How delivery routes, formulation, concentration and timing influence the success of phage therapy. J. Pharm. Pharmacol. 2011, 63, 1253-1264. [CrossRef] [PubMed]

108. Babalova, E.G.; Katsitadze, K.T.; Sakvarelidze, L.A.; Imnaishvili, N.S.; Sharashidze, T.G.; Badashvili, V.A.; Kiknadze, G.P.; Meipariani, A.N.; Gendzekhadze, N.D.; Machavariani, E.V.; et al. Preventive value of dried dysentery bacteriophage. Zhurnal Mikrobiol. 1968, 45, 143-145.

109. Litvinova, A.M.; Chtetsova, V.M.; Kavtreva, I.G. Evaluation of efficacy of the use of coli-Proteus bacteriophage in intestinal dysbacteriosis in premature infants. Voprosy Okhrany Materinstva i Detstva 1978, 23, 42-44.

110. Meladze, G.D.; Mebuke, M.G.; Chkhetia, N.S.; Kiknadze, N.I.; Koguashvili, G.G.; Timoshuk, I.I.; Larionova, N.G.; Vasadze, G.K. The efficacy of staphylococcal bacteriophage in treatment of purulent diseases of lungs and pleura. Grudn. Khir. 1982, 1, 53-56.

111. Bogovazova, G.G.; Voroshilova, N.N.; Bondarenko, V.M. The efficacy of Klebsiella pneumoniae bacteriophage in the therapy of experimental Klebsiella infection. Zhurnal Mikrobiol. Epidemiol. Immunobiol. 1991, 4, 5-8.

112. Johnson, R.P.; Gyles, C.L.; Huff, W.E.; Ojha, S.; Huff, G.R.; Rath, N.C.; Donoghue, A.M. Bacteriophages for prophylaxis and therapy in cattle, poultry and pigs. Anim. Health Res. Rev. 2008, 9, 201-215. [CrossRef]

113. Smith, H.W.; Huggins, M.B. Effectiveness of phages in treating experimental Escherichia coli diarrhoea in calves, piglets and lambs. J. Gen. Microbiol. 1983, 129, 2659-2675. [CrossRef] [PubMed]

114. O'Flaherty, S.; Ross, R.P.; Meaney, W.; Fitzgerald, G.F.; Elbreki, M.F.; Coffey, A. Potential of the polyvalent anti-Staphylococcus bacteriophage $\mathrm{K}$ for control of antibiotic-resistant staphylococci from hospitals. Appl. Environ. Microb. 2005, 71, 1836-1842. [CrossRef]

115. Ngassam-Tchamba, C.; Duprez, J.N.; Fergestad, M.; De Visscher, A.; L'Abee-Lund, T.; De Vliegher, S.; Wasteson, Y.; Touzain, F.; Blanchard, Y.; Lavigne, R.; et al. In Vitro and in Vivo Assessment of Phage Therapy against Staphylococcus Aureus Causing Bovine Mastitis. J. Glob. Antimicrob. Resist. 2020, 22, 762-770. [CrossRef] [PubMed]

116. Meira, E.B.S.; Rossi, R.S.; Teixeira, A.G.; Kaçar, C.; Oikonomou, G.; Gregory, L. Bicalho, R.C. The effect of prepartum intravaginal bacteriophage administration on the incidence of retained placenta and metritis. J. Dairy Sci. 2013, 96, 7658-7665. [CrossRef] [PubMed] 
117. Titze, I.; Lehnherr, T.; Lehnherr, H.; Krömker, V. Efficacy of bacteriophages against Staphylococcus aureus isolates from bovine mastitis. Pharmaceuticals 2020, 13, 35. [CrossRef] [PubMed]

118. Mendes, J.J.; Leandro, C.; Corte-Real, S.; Barbosa, R.; Cavaco-Silva, P.; Melo-Cristino, J.; Górski, A.; Garcia, M. Wound healing potential of topical bacteriophage therapy on diabetic cutaneous wounds. Wound Repair. Regen. 2013, 21, 595-603. [CrossRef] [PubMed]

119. Wall, S.K.; Zhang, J.; Rostagno, M.H.; Ebner, P.D. Phage therapy to reduce preprocessing Salmonella infections in market-weight swine. Appl. Environ. Microbiol. 2010, 76, 48-53. [CrossRef]

120. Jamalludeen, N.; Johnson, R.P.; Shewen, P.E.; Gyles, C.L. Evaluation of bacteriophages for prevention and treatment of diarrhea due to experimental enterotoxigenic Escherichia coli O149 infection of pigs. Vet. Microbiol. 2009, 136, 135-141. [CrossRef] [PubMed]

121. Saez, A.C.; Zhang, J.; Rostagno, M.H.; Ebner, P.D. Direct Feeding of Microencapsulated Bacteriophages to Reduce Salmonella Colonization in Pigs. Foodborne Pathog. Dis. 2011, 8, 1269-1274. [CrossRef]

122. Seo, B.J.; Song, E.T.; Lee, K.; Kim, J.W.; Jeong, C.G.; Moon, S.H.; Son, J.S.; Kang, S.H.; Cho, H.S.; Jung, B.Y.; et al. Evaluation of the broad-spectrum lytic capability of bacteriophage cocktails against various Salmonella serovars and their effects on weaned pigs infected with Salmonella Typhimurium. J. Vet. Med. Sci. 2018, 80, 851-860. [CrossRef]

123. Drilling, A.; Morales, S.; Boase, S.; Jervis-Bardy, J.; James, C.; Jardeleza, C.; Tan, N.C.; Cleland, E.; Speck, P.; Vreugde, S.; et al. Safety and efficacy of topical bacteriophage and ethylenediaminetetraacetic acid treatment of Staphylococcus aureus infection in a sheep model of sinusitis. Int. Forum Allergy Rhinol. 2014, 4, 176-186. [CrossRef]

124. Bach, S.J.; Johnson, R.P.; Stanford, K.; McAllister, T.A. Bacteriophages reduce Escherichia coli O157: H7 levels in experimentally inoculated sheep. Can. J. Anim. Sci. 2009, 89, 285-293. [CrossRef]

125. Atterbury, R.J.; Van Bergen, M.A.P.; Ortiz, F.; Lovell, M.A.; Harris, J.A.; De Boer, A.; Wagenaar, J.A.; Allen, V.M.; Barrow, P.A. Bacteriophage Therapy To Reduce Salmonella Colonization of Broiler Chickens. Appl. Environ. Microbiol. 2007, 73, 4543-4549. [CrossRef] [PubMed]

126. Ma, Y.-H.; Islam, G.S.; Wu, Y.; Sabour, P.M.; Chambers, J.R.; Wang, Q.; Wu, S.X.Y.; Griffiths, M.W. Temporal distribution of encapsulated bacteriophages during passage through the chick gastrointestinal tract. Poultry Sci. 2016, 95, 2911-2920. [CrossRef] [PubMed]

127. Hammerl, J.A.; Jäckel, C.; Alter, T.; Janzcyk, P.; Stingl, K.; Knüver, M.T.; Hertwing, S. Reduction of Campylobacter jejuni in Broiler Chicken by Successive Application of Group II and Group III Phages. PLoS ONE 2014, 9, e114785.

128. Goode, D.; Allen, V.M.; Barrow, P.A. Reduction of experimental Salmonella and Campylobacter contamination of chicken skin by application of lytic bacteriophages. Appl. Environ. Microbiol. 2003, 69, 5032-5036. [CrossRef]

129. Colom, J.; Cano-Sarabia, M.; Otero, J.; Aríñez-Soriano, J.; Cortés, P.; Maspoch, D.; Llagostera, M. Microencapsulation with alginate/CaCO 3: A strategy for improved phage therapy. Sci. Rep. 2017, 7, 1-10.

130. El-Gohary, F.A.; Huff, W.E.; Huff, G.R.; Rath, N.C.; Zhou, Z.Y.; Donoghue, A.M. Environmental augmentation with bacteriophage prevents colibacillosis in broiler chickens1. Poult. Sci. 2014, 93, 2788-2792. [CrossRef]

131. Bhandare, S.; Colom, J.; Baig, A.; Ritchie, J.M.; Bukhari, H.; Shah, M.A.; Sarkar, B.L.; Su, J.; Wren, B.; Barrow, P.; et al. Reviving Phage Therapy for the Treatment of Cholera. J. Infect. Dis. 2019, 219, 786-794. [CrossRef]

132. Trigo, G.; Martins, T.G.; Fraga, A.G.; Longatto-Filho, A.; Castro, A.G.; Azeredo, J.; Pedrosa, J. Phage therapy is effective against infection by Mycobacterium ulcerans in a murine footpad model. PLoS Negl. Trop Dis. 2013, 7, e2183. [CrossRef]

133. El-Aziz, A.M.A.; Elgaml, A.; Ali, Y.M. Bacteriophage Therapy Increases Complement-Mediated Lysis of Bacteria and Enhances Bacterial Clearance After Acute Lung Infection With Multidrug-Resistant Pseudomonas aeruginosa. J. Infect. Dis. 2019, 219, 1439-1447. [CrossRef] [PubMed]

134. Jeon, J.; Ryu, C.-M.; Lee, J.-Y.; Park, J.-H.; Yong, D.; Lee, K. In Vivo Application of Bacteriophage as a Potential Therapeutic Agent To Control OXA-66-Like Carbapenemase-Producing Acinetobacter baumannii Strains Belonging to Sequence Type 357. Appl. Environ. Microbiol. 2016, 82, 4200-4208. [CrossRef]

135. Chadha, P.; Katare, O.P.; Chhibber, S. In vivo efficacy of single phage versus phage cocktail in resolving burn wound infection in BALB/c mice. Microb. Pathogen. 2016, 99, 68-77. [CrossRef] [PubMed]

136. Prazak, J.; Iten, M.; Cameron, D.R.; Save, J.; Grandgirard, D.; Resch, G.; Goepfert, C.; Leib, S.L.; Takala, J.; Jakob, S.M.; et al. Bacteriophages Improve Outcomes in Experimental Staphylococcus aureus Ventilator-associated Pneumonia. Am. J. Respir. Crit. Care Med. 2019, 200, 1126-1133. [CrossRef] [PubMed]

137. Yen, M.; Cairns, L.S.; Camilli, A. A cocktail of three virulent bacteriophages prevents Vibrio cholerae infection in animal models. Nature Comm. 2017, 8, 1-7. [CrossRef]

138. Schmelcher, M.; Powell, A.M.; Camp, M.J.; Pohl, C.S.; Donovan, D.M. Synergistic streptococcal phage $\lambda S A 2$ and B30 endolysins kill streptococci in cow milk and in a mouse model of mastitis. Appl. Micorb. Biotechnol. 2015, 99, 8475-8486. [CrossRef] 